\title{
Criterios de la justicia: coacción, deber, persona
}

\author{
Criteria of Justice: Compulsion, Duty, Person
}

\author{
Francisco CARPINTERO \\ Universidad de Cádiz \\ francisco.carpintero@uca.es
}

RECIBIDO: 12/11/2019/ ACEPTADO: 12/03/2020

\begin{abstract}
Resumen. La teoría y la filosofía del derecho son reflexiones sobre la justicia, y la máxima aspiración de ellas -o ella- es mostrar porqué el derecho debe ser obedecido, es decir, en qué consiste y cómo se manifiesta el deber jurídico. Pero la teorización sobre el derecho corre hoy el peligro de perderse entre la teoría de la democracia como culmen de toda justicia, o alguna exposición o teoría sobre los derechos humanos. El autor pretende aludir a los momentos ontológicos (las cosas) y a los inesquivables datos metafísicos que son el deber y la personalidad humana.
\end{abstract}

Palabras clave: Ontología, metafísica, deber, persona, justicia.

\begin{abstract}
The theory and philosophy of law are reflections on justice, and their maximum aspiration -or its- is to show why the law should be obeyed, that is, what is a legal duty and how it shows up. But theorizing about law today runs the risk of getting lost between the theory of democracy as the culmination of all justice, or some exposition or theory about human rights. The author purports to allude to the ontological moments (the things) and to the inescapable metaphysical data that underlie both duty and human personhood.
\end{abstract}

Keywords: Ontology, metaphysics, duty, person, justice.

E ste estudio no es más que una simple extroversión, no tanto una colección de pensamientos eruditos cuanto un abrir el corazón, de lo que considero como justicia y de cómo esta se diferencia de la fuerza organizada socialmente.

La ciencia jurídica, de la mano de la justicia, consiste ante todo en saber evaluar. En este punto son distintos el derecho penal y el derecho civil. Pues el derecho penal sanciona al que es culpable, y el derecho civil no requiere normalmente de ninguna culpabilidad. Es cierto que el derecho civil tiende, quizá cada vez en mayor medida, a considerar lo que genéricamente llamamos la buena fe; pero normalmente no tiene en cuenta esta disposición del ánimo: si alguien no puede pagar la hipoteca de su casa por razones ajenas a su voluntad, simplemente el banco se hace con la casa.

Por lo demás, al hablar de la injusticia, esto es, del ejercicio prepotente de la fuerza, algunos se imaginan hombres malos que son como dragones, que ejercen un despotismo sobre los que son inferiores a ellos en fuerza. Hoy sigue habiendo tiranos al antiguo estilo, y precisamente porque ese estilo es dema- 
siado antiguo, no interesa ahora. La violencia proviene desde los abogados y desde los jueces incompetentes, desde los legisladores que son la voz fiel de su amo, desde esa inmensa administración pública -siempre «necesitada de personal»- que tiende a extenderse como una mancha de aceite quitándonos capacidades a los ciudadanos.

\section{METAFÍSICA Y ONTOLOGÍA}

Hablaba de saber evaluar, y toda evaluación requiere 'cosas'. Podemos llamar cosas a una compraventa, a un arrendamiento, a un usufructo, al honor y buen nombre, etc. Estas cosas no se nos presentan al modo de los cuerpos físicos, que pueden ser tocados con la mano, sino bajo las formas de conceptos. ¿Conceptos generales inducidos enteramente desde la observación por el hombre, o conceptos verdaderamente universales?

$\mathrm{Si}$ alguien no admite la posibilidad de que haya conceptos universales, no puede trabajar en el derecho. En la filosofía, e históricamente en la teología, se cuestionan de hecho este tipo de conceptos, pero no así en el derecho, porque es el plano jurídico donde se nos manifiesta su necesaria universalidad, ya que nadie, que haya sido multado por exceso de velocidad, puede indicar que él es inocente porque no sabe lo que es la velocidad o lo que son 150 kilómetros por hora; o que él utiliza un lenguaje distinto al de la policía de tráfico que lo denuncia porque usa otro meta-lenguaje. Esa persona, si es verdad lo que dice, no debe tener como destino la multa o la cárcel sino, en el caso extremo, un centro psiquiátrico. El deber sólo puede resultar desde la universalidad, de lo que Kant llamaba imperativos absolutos o categóricos que todos pueden y deben conocer: se nos entrelazan dos sentidos algo distintos de la palabra 'deber'.

Hablaba de la ontología. Sucede que las cosas requieren -¿cómo decirlo? - de una cierta corporeidad. Pues una compraventa o un alquiler puede, incluso, constituirse ante un notario y son actos públicos que también se corporeizan en papeles. Hay que hablar de ontología para referirse a ellas; pues una compraventa siempre será 'algo' distinto de un arrendamiento.

Más allá del conocer ontológico hay otras realidades que son más sutiles porque se salen del plano de esa cierta corporeidad y no pueden ser percibidas por los sentidos. Sería el caso de la índole personal del ser humano, o del deber, o de 'tener un derecho'. Estas últimas realidades poseen una existencia metafísica. 
Si alguien no admite la ontología y, por ende, tampoco la metafísica, no estará en condiciones de trabajar en el mundo singular del derecho. Y el problema está en que bastantes filósofos han negado estas realidades a lo largo del segundo milenio.

\section{II. ¿LA ONTOLOGÍA ES POSIBLE? El NOMINALISMO Y EL CASO SINGULAR DEL DERECHO}

Muchas personas que reflexionan sobre los temas generales del conocimiento se han llamado nominalistas. Con esto quieren decir que nadie puede saber lo que es un concepto realmente jurídico o lo que es el deber. El que trabaja en el derecho no puede ser nominalista porque, si se proclama así, carecerá incluso del index más inmediato para comenzar su trabajo, porque no podrá relacionar un comportamiento con las reglas que lo regulan: el solo flatus voci de las palabras sirve muy poco más allá de suscitar reacciones emotivas. Necesitamos 'índices' para relacionar lo que observamos con las reglas que apresan a lo observado, tal como establecía John Austin en $1830^{1}$.

El problema que se nos ha suscitado, desde el siglo XVII, es el del nominalismo en la filosofía práctica. Parece que lo más procedente es ante todo ocuparse de este tema. Estas filosofías producen la impresión de que sus autores, o quienes las han representado, han querido poner a las personas unas anteojeras que determinan su comportamiento censurándolo severamente, en nombre de un sistema filosófico. Cuenta la historia que un día una niña le enseñó una mariposa a un botánico y le preguntó: «¿Qué es esto?». El botánico le contestó: «Es una margarita». Y la niña le dijo «¿Por qué me dices que es una planta si ves que es un insecto?». El otro le contestó: «Porque soy un botánico». Ciertamente, el que profesa una filosofía previa a la

1 Austin, J., Lectures on Furisprudence or the Philosophy of Positive Law, $5^{\mathrm{a}}$ ed. John Murray, London, 1911, p. 106. Aquí establece que, el primer index son los principios morales más elementales. En otros momentos indica que, el index ha de ser la utilidad social guiada por las consecuencias. Lectures, p. 112. Tiende a pensar más a lo largo de su obra que tal index no puede ser ni la intuición moral (p. 145) ni el moral sense (p. 153).

El lector puede dispensar el abundante recurso a citas propias. Para expresar mi opinión me centré ante todo en mis publicaciones, con algunos apoyos ajenos. Con buena voluntad, se puede considerar que reitero en algún modo el estilo de lo que expuso Roderico Antonio Fabricio en su Dissertatio «De argumento ab Amore», Helmstadt, 1723. 
investigación puede exponer según el esquema de «planteamiento, nudo y desenlace» que elude muchos problemas, pero puede hacer eso porque ha hecho voto de desconocimiento voluntario de lo que, a veces, es importante. Y los que no hemos hecho ningún voto de pobreza en el conocimiento de la realidad estamos obligados a practicar esa rationem reddere de lo que acontece en nuestras vidas.

Alguien puede preguntarse a qué vienen estas digresiones en el momento de explicar por qué el derecho ha de ser más que simple coacción organizada. Se trata de ser fieles al derecho que vivimos todos los días, y todos nos movemos con realidades ontológicas, como son las cosas que consisten, por ejemplo, en la propiedad sobre nuestra vivienda, o con realidades metafísicas, como como son los derechos y los deberes que nos competen a mí y a los otros.

Estas últimas realidades, unidas a otros derechos humanos que suelen estar recogidos en Declaraciones más o menos solemnes, son las que nos separan de la simple fuerza. Si el gobernante respeta las propiedades, los matrimonios y otras cosas más, esas realidades constituyen de facto unas 'sociedades intermedias' que atan sus manos con tanta o más eficacia que lo que Rousseau llamó sociedades intermedias. A cada uno lo suyo: existen realmente lo que usualmente llamamos sociedades intermedias para referirnos a cosas tales como un club recreativo, cultural, un colegio o una Universidad, a una confesión religiosa o a una Cofradía Penitencial de Semana Santa (pensemos en Andalucía), y ellas constituyen también derechos del hombre, y por ello cauces para el razonamiento jurídico y para evitar abusos del poder. Ernst-Wolfgang Böckenförde ha dejado varios estudios sobre este último tema².

Es patente que con las 'sociedades intermedias' nos sucede lo mismo que con el término 'deber', que también posee una cierta ambivalencia. La fidelidad al derecho, dejando ahora de lado los derechos humanos, requiere recoger ambas dimensiones de lo que estamos llamando sociedades intermedias. Pero, como el lector ya ha comprobado, nos interesa más aquella primera vertiente de la metafísica y de la ontología de algunos conceptos.

2 Por ejemplo, BöCKENFÖRDE, E-W., Estudios sobre el Estado de Derecho y la democracia, trad. R. Agapito, Trotta, 2000. O bien, ID., «Die Bedeutung der Unterschied von Staat und Gesellschaft in demokratischen Sozialistaat der Gegenwart», en Staat und Gesellschaft, Wissenschaftliche Buchgesellschaft Darmstadt, 1976.

Centra más este tema HäBERLE, P., La libertad fundamental en el Estado constitucional, trad. J. Seligman-C. Landa, Comares, Granada, 2003. 


\section{Escarceos bistóricos}

Desde el siglo XI, el nominalismo ha compuesto el cuadro pintado en el primer momento y, desde luego, ha sido el dominante. Los nominales ${ }^{3}$ negaron la existencia de los conceptos universales y de todo lo que se refiriera a la metafísica entendida en su sentido más corriente. Éste es un tema que ya está estudiado y me remito a esos estudios ${ }^{4}$.

Su actitud tuvo mucho de apasionada y de anárquica, y no respondió a un solo motivo. Uno, que está en la base de todos ellos, fue la repugnancia para admitir que Dios tiene las manos atadas por un orden nouménico superior a Él mismo, aunque se indique que tal orden superior es su misma Inteligencia y Bondad. Pero esto plantea un problema inmediato: que todo hombre reconoce establecidas ya en sus conciencias las prohibiciones de mentir o de molestar a los demás. Esto implicaba admitir una 'ley racional' objetiva e igual para todos que 'reside' en nuestro cerebro. Salvaron este problema distinguiendo entre esa ley que conocemos concreta y 'materialmente', a la que llamaron lex indicans, y la orden o mandato de Dios -puesto que estamos creados por Él- que ordena cumplir lo que todos ven claramente en la lex indicans; a esta segunda faceta de la ley natural la llamaron lex imperans seu praecipiens. La primera ley es una realidad humana porque sólo 'está' en las razones de los hombres; la segunda es una realidad directamente divina, aunque está en nuestra razón. Ya que esos contenidos cognoscibles en la razón humana no podían ser esencias metafísicas (pues entonces vincularían inmediatamente sin necesidad de ninguna lex imperans), quedaron sin nombres, y los más modernos como Pufendorf, explicaron que eran simples 'modos' o modi, unas formas ínfimas de ser.

3 Prefiero este nombre al de 'nominalistas' porque el primer nominalista coherente del segundo milenio fue Thomas Hobbes. Este inglés abanderó el nominalismo para, entre otras cosas, romper la vinculación del hombre con Dios. Entendió que así negaba la posibilidad de apelar a una justicia que fuera superior a la establecida legalmente porque no existía nada superior a las órdenes del legislador.

En cambio, los nominales de la Edad Media, entendieron que el ser humano estaba por encima y antes de las leyes naturales y humanas, porque él actuaba de acuerdo con la Prima justitia Dei. Hay similitud entre Hobbes y estos otros escolásticos solamente en la superficie de los términos.

4 CaRPintero, F., El desarrollo de la idea de libertad personal en el pensamiento medieval, Universidad Panamericana-Porrúa, México D.F., 2006; ID., Fusticia y ley natural: Tomás de Aquino, y los otros escolásticos, Servicio de Publicaciones de la Universidad Complutense, Madrid, 2004; ID., La ley natural. Una realidad aun por explicar, UNAM, México, 2013; ID., «El desarrollo de la facultad individual en la Escolástica», en ID. (ed.), El derecho subjetivo en su historia, Universidad de Cádiz, 2003, pp. 35-288. 
¿Se puede hablar de una ley humana que no ha sido constituida por el consenso de los hombres? Sucede -indicaba Scoto- que la luz del intelecto no es propiamente una ley porque, aunque indique qué conviene hacer, no impera ${ }^{5}$. Pero algunas leyes generales que tratan de lo que hay que hacer, están prefijadas en la voluntad divina, no en el intelecto, de forma que las precede un acto de la voluntad de Dios. La libertad o voluntad de Dios añade a estas leyes el imperium naturale a través de la lex imperans seu praecipiens.

Para estos nominalistas, las tendencias naturales de los hombres quedaron sin explicación propiamente normativa. Para los nominales, la naturaleza o 'lo natural' es simplemente lo que está ahí, sin relevancia propiamente moral. Suárez explicaba, en la coronación de este nominalismo, que «La ley natural no se regula por su adecuación a la naturaleza sensitiva, sino a la racional». La sensitiva existe sólo como materia contracta por la racionalidad» ${ }^{6}$. Suárez culminó su nominalismo volviendo a su pensamiento exquisitamente intelectual, y nos explicó que la ley en general (y por tanto la Ley natural) es una realidad que solamente puede pertenecer a la naturaleza intelectual, esto es a la mente ${ }^{7}$, y en el súbdito la ley sólo puede consistir en un acto mental ${ }^{8}$. Por ello las inclinaciones de los sentidos no pueden ser entendidas formalmente, como si ellas midieran, sino participativamente, como lo que es medido por la ley ${ }^{9}$. Ciertamente -prosigue Suárez- Santo Tomás, en la I-II, q. 95, art. 4 ha mantenido otra consideración del problema: pero es que, como explicaba ya Conrado, Tomás se ha dejado influir por la forma de hablar de los juristas ${ }^{10}$.

5 «Lex ergo naturae vel inditum lumen intellectus non est propria lex, quia etsi indicet quae oportet facere, non tamen imperat... Accedit, quod leges aliquae generales de operabilibus dictantes, praefixae sunt a voluntate divina, et non ab intellectu, ut praecedit actum voluntatis divinae, quia in illis legibus non invenitur necessitas ex terminis». Fohannis Duns Scoti Doctoris Subtilis Ordinis Minorum Summa Theologica. Ex universis operibus ejus concinnata, juxta ordinem et dispositionem S. Thomae Aquinatis per Fratrem Hieronymus de Montefortino, Romae, 1728, I-II, q. 90 .

6 «Lex naturalis non regulatur per convenientiam ad naturam sensitivam; sed et rationalem. Sensitivam autem respicit solum ut contractam, et speciali modo perfectum per differentiam rationalem». SuÁreZ, F., Tractatus de Legibus ac Deo legislatore, Conimbricae, 1612, L. II, cap. 17, \$ 6.

7 «Legem esse aliquid pertinens ad naturam intellectualem... Est ergo lex aliquid ad mentem pertinens». Op. cit., Tractatus..., L. I, cap. $4, \$ 2$.

8 «Lex in subdito solum residet in actu mentis». Op. cit., Tractatus..., L. I, cap. 4, $\$ 5$.

9 «Non formaliter, ut lex est mensura, sed participative, ut solet dici de mensurato per legem». Op. cit., Tractatus..., L. I, cap. $1, \$ 3$.

10 «Atque talium interpretatur Con... ubi ita exponit Juristarum opinionum, ut dicit, Divum Thomam loquuntur fuisse more illorum, licet Philosophi aliter loquantur». Op. cit., Tractatus..., cit., L. II, cap. $17, \$ 4$. 
(Santo Tomás no había explicado esto en el lugar indicado por Suárez, sino en la I-II, q. 94 , art. 2$)^{11}$.

El siglo XV compuso el momento más apasionante en la historia de este problema. Lo comenzó Juan de Gerson y le siguieron Conrado de Summenhart, Pedro Alliacus, Jacobo Almain o Gabriel Biel, entre otros autores menos conocidos. Ellos fueron el verdadero puente entre el nominalismo medieval y el moderno ${ }^{12}$ : para la Modernidad, las explicaciones de Juan Duns Scoto había quedado demasiado lejos en la historia, y Ockham no fue bien recibido por su excesiva radicalidad. Gerson fue el verdadero educador de la Edad Moderna, que lanzó esta filosofía a la Modernidad.

Si prescindimos de Hobbes y de otros ingleses que siguieron su fenomenismo, las doctrinas continentales sobre el derecho natural encontraron sus referentes, en el siglo XVII, en las obras de Hugo Grocio y de Samuel Pufendorf. Los discípulos de este último compusieron la línea más radical, es decir, más individualista, contractualista y en ocasiones materialista, de la Ilustración, tal como se manifiesta con Thomasius, Gundling, Schmauß o Koehler. Los partidarios de uno y otro se opusieron, a veces, con cierta violencia ${ }^{13}$.

11 La tendencia a considerar que la naturaleza es solamente el reino de la necesidad, esto es, de lo ya-dado y sin relevancia para la ética, es antigua. Se manifestó abiertamente en Juan Duns Scoto, y le siguieron sus discípulos de los siglos XIV y XV. Para un conocimiento más detallado, vid. Carpintero, F., El derecho subjetivo..., op. cit., pp. 173-188; e ID., El desarrollo de la idea..., op. cit., pp. 129-164.

Resultó así que lo que se conoce como la idea moderna de la naturaleza, es realidad típicamente medieval en la Escuela de los Nominales. Los jesuitas españoles en el cambio de siglos del XVI al XVII siguieron estas tesis de los Nominales. Así se explica en BASTIT, M., Naissance de la loi moderne. La pensée de la loi de saint Thomas à Suárez, PUF, 1990.

12 Carpintero, F., «El desarrollo de la facultad...», op. cit.

13 Ha sido corriente leer «Grocio y Pufendorf», como si ambos autores hubieran mantenido una relación de precedente a realidad madura. No fue así. Gottfridus Mascovius -uno de los iusnaturalistas más leído en la Edad Moderna- opuso el uno al otro. Vid. MASCOviUs, G., sus Quaestiones selectae iuris naturae et gentium inter Grotium et Pufendorfium, Leipzig, 1768. Autores que aceptaron a Grocio pero no a Pufendorf fueron, entre otros muchos, Beckmann, Boecler o Vigelius. Incluso un autor tan moderado por lo general, como fue Daniel Nettelbladt, entendía que Samuel Pufendorf había sido el gran iniciador de la Iuris Naturalis Disciplina, a la que libró de «la barbarie de los escolásticos», y parece que también Hugo Grocio quedaba incluido en esta barbarie. Escribía «Licet vero Puffendorfius vestigia Grotii in multis presset, pro felicissimo tamen jurisprudentiae naturalis reformatore habendus. Scholasticorum barbariem enim, quae nondum plane extirpatata erat, extirpavit funditus et licet non fuerit primus... proprius tamen ad systematicham artis formam ei dedisse». $\$ 31$. NeTtELbLaDT, D., Systema elementare universae jurisprudentiae naturalis in usum praelectionum academicarum adornatum, $3^{\mathrm{a}}$ ed., Halae Magdeburgicae, 1767, \$31. 
Grocio fue un autor aún de transición: se inserta en varios nervios del derecho romano, tiene en cuenta las filosofías escolásticas tal como fueron expuestas por Molina y Suárez y admite la Lex aeterna de Dios. Esto último le costó el desdén de buena parte de los iusnaturalistas que le siguieron. Además, en el tráfico de ideas del siglo XVII, la remisión a un escolástico, aunque fuera de los siglos XVI o XVII, llevaba a una descalificación fulminante entre los autores progresistas del derecho natural. Samuel Pufendorf no citó a un solo escolástico y de la tradición jurídica exterior, y entre los juristas anteriores, sólo mencionó a François Conan y Fernando Vázquez de Menchaca, como consta por el «Index rerum et materiarum» que figura al final de su obra principal.

Pero tanto Grocio como Pufendorf estaban empapados de las obras escolásticas. Sólo que este último, a diferencia de Grocio, se fundamenta de hecho más directamente a Suárez y a las filosofías de los nominales de la Baja Edad Media. Tal es el contenido de sus explicaciones más teóricas. Para él, los preceptos del Derecho natural son solamente 'modos' (modi) «superimpuestos a los seres inteligentes» ${ }^{14}$. (Pufendorf se mostró especialmente imaginativo a la hora de crear terminología). Estos modi no poseen en modo alguna una naturaleza 'real', en el sentido más amplio del término, y expulsa a las 'cosas' fuera del derecho natural: «Enimvero ut Res, quatenus sub obiectum iuris, in censum entium moralium proprie referamus, opus non videtur ${ }^{15}$. Lógicamente, las leyes no deben ser obedecidas por lo que ellas expresan, sino por la voluntad de quien las impone ${ }^{16}$. De forma coherente con lo expresado, concluye que «Decimos que una nación es buena moralmente... cuando se adecúa a la ley; y es mala la que discrepa de ella. Pues la razón formal de la bondad o de la malicia consiste en su hábito o relación determinativa a la norma directiva que llamamos ley» ${ }^{17}$.

Se adecúa plenamente a Suárez cuando este jesuita escribía que «la razón de ser» de la ley reside en el imperium del que gobierna ${ }^{18}$. Es preciso tener en cuenta que el idioma latino el imperium es la fuerza, y por ello el jefe del

14 Pufendorf, S., De Iure naturae et gentium libri octo, Francofurti et Lipsiae, 1759, L. I, cap. I, $\$ 3$.

15 Ibid., L. I, cap. I, $\$ 16$

16 «Actio necesaria est, quam ex lege aut iustis superioris omnino facere tenetur ius, cui ea lex aut iussum fuit datus. In hoc consistit haecce actionum moralium necessitas». Ibid., L. I, cap. VII, $\$ 2$.

17 «Actionem bonam moraliter... dicimus, que cum lege congruit; malam, quae ab eadem discrepat. Scilicet formalis ratio bonitatis et malitiae actionum consistit in habitudine, seu relatione determinativam ad normam directivam, quam dicimus legem». Ibid., L. I, cap. VII, $\$ 3$.

18 «Imperium quoad substantiam suam in ipsa voluntate consistit, ut dixi». Op. cit., Tractatus.., L. II, cap. $1, \$ 6$. 
ejército, cuando actuaba como director de Roma, era llamado imperator. Pero Pufendorf no se atreve a prolongar la doctrina suareziana de los derechos subjetivos naturales. Sí ofrece dos novedades: él entiende que la libertad de cada individuo forma como un cerco en torno a la persona que, por sí mismo, es lo más difusivo posible, y llama a esta figura una sphaera moralis, a la que trató, a modo de apéndice, en un estudio anterior, el «Tractatus de jurisprudentia universalis». La otra novedad sí fue más importante, ya que explicó que, si consideramos a la naturaleza como contradistincta de Dios, la naturaleza no nos presta a través de sus leyes una fuerza para actuar ${ }^{19}$. Por lo demás, del mismo modo que los nominales anteriores, usó profusamente el término persona. Pero ahora es una persona que se impone por ella misma, por el sonido de su voz, ya que no obtiene el respaldo normativo necesario para actuar: no hizo ninguna referencia a la Prima justitia Dei o a cualquier constitución divina anterior a la ley natural.

Los nominales habían distinguido la lex indicans de la lex imperans. Aquella era una realidad estrictamente racional mientras permanezca el uso de la naturaleza racional; esta última era una realidad divina que era necesario suponer para explicar la capacidad de imposición normativa de lo que muestra la lex indicans. Eran dos zonas excesivamente heterogéneas en su origen, alcance y estructura. Si los hombres somos substantias, y la ley natural se compone de 'modos', realmente, ¿merece la pena obedecer a realidades de tan bajo nivel? ¿Hay que creer que Dios quiere conductas tan insignificantes metafísica y ontológicamente? Ciertamente, están ordenadas o mandadas por Dios, pero ¿puede considerarse pecado obrar contra tan poca cosa? Los nominalistas, para elevar el nivel en el orden del ser a la lex indicans, identificaron a tal ley con la razón misma, de forma que esta ley existiría mientras existiera la naturaleza racional, de la que participan de alguna forma Dios, los ángeles, los demonios y los hombres, y que está presente de 'forma objetiva' en cada uno de estos seres. Trataron de suplir la poca entidad de ella realzando su inmutabilidad.

Es por esto por lo que Gregorio de Rímini, forma usual de llamar a Gregorius Ariminiensis, explicaba en el siglo XIII, que «Si por un imposible la razón divina, o Dios mismo no existiera o poseyera una razón equivocada, aún

$19 \ll$ Si per naturam intelligamur universitas rerum creaturarum, Deo contradistincta, tunc negamus, potentiam naturae esse ipsius Dei potentiam». Op. cit., De iure naturae et gentium.., L. II, cap. 2, \$2. 
así, si alguien actuara contra la recta razón angélica o humana o cualquier otra, fuera la que fuera, pecaría ${ }^{20}$. Más tarde, Guillermo de Ockham, sin ser nada original, indicaba que «Si por un imposible Dios no existiera, que es la razón divina, o si esa ratio estuviera equivocada, quien actuara contra la recta razón, angélica, humana o cualquier otra, pecaría. El pecado es la carencia voluntaria de conformidad a la razón recta debida por la voluntad» ${ }^{21}$. Finalmente, Gabriel Biel, con el que nos internamos en el siglo XVI, repetía que «Si por un imposible Dios no existiera, o la razón divina estuviera equivocada, quien obrara contra la recta razón angélica o humana, o contra otra cualquiera, cometería pecado» ${ }^{22}$. Notemos que estamos ante un arco histórico que va desde el siglo XIII al XVI.

Explicaron, desde los tiempos de Gregorio de Rímini, que la ley natural sería válida, aunque Dios no existiera, de modo que quien la desobedeciera, cometería un pecado filosófico (no moral o teológico) contra la recta ratio ${ }^{23}$.

Pero al perderse el puente entre la razón 'natural' y Dios, la ley natural quedó sin fundamentos normativos. En la pugna entre la lex indicans y la lex imperans, triunfó ampliamente el momento simplemente humano, desplazando a Dios, y la Iuris naturalis disciplina se fue secularizando progresivamente.

$20 \ll$ Si per imposibili ratio divina sive Deus ipse non esset aut ratio illa esse errans, adhuc, si quis ageret contra rectam rationem angelicam vel humanam aut aliam aliquam, si qua esset, peccaret». Gregorius Arimiensis lectura super Primum et Secundum Sententiarum, Tomus VI, Super Secundum, 1980, Dist. 34-37, q. 1. Continúa la cita indicando que «Et si nulla penitus esset ratio recta adhuc, si quis agere contra illud quod agendum esse dictaret ratio aliqua recta, si aliqua esse, peccaret. Et ideo in ponendo conclussionem dixi peccatum esse agere contra rectam rationem <seu> contra id quod agendum esset secundum rectam rationem».

$21 \ll$ Nam per si impossibile Deus non esset, qui est ratio divina: aut ratio illa divina esset errans, adhuc si quis ageret contra recta rationem angelicam, vel humanam, vel aliam aliquam, si qua esset, peccaret. Peccatum est voluntaria carentia conformitatis ad rationem rectam debiti voluntati». Magistri Guilhelmi de Ockham super potestate de summi pontificis octo quaestionum decisiones, Lyon, 1496, L. II, Dist. 28, q. unica, p. 165-E.

22 «Nam per si impossibile Deus non esset, qui est ratio divina: aut ratio illa divina esset errans, adhuc si quis ageret contra recta rationem angelicam, vel humanam, vel aliam aliquam, si qua esset, peccaret. Peccatum est voluntaria carentia conformitatis ad rationem rectam debiti voluntati». BIEL, G., Commentarii doctissimi in IIII Sententiarum libros, Brixiae, 1574, L. II, Dist. 28, q. unica, p. 165 -E.

23 Scoto había explicado que «Quare non intellecto voluntatis imperio adstringentis alios ad servandam legem, quaecumque raepresentarentur contra judicium rationis, esse reputanda mala, non moralia, vel theologica, sed mala naturae et philosophica... Homo faciens contrarium, contra naturam, comitti malum, sed non esse tale malum reputandum demeritorium, aut offensa Dei». Fohannis Duns Scoti, op. cit., I-II, q. 91, art. 2. 


\section{La filosofía materialista}

Las cartas ya están expuestas sobre la mesa de un modo -espero- bien visible. De acuerdo con lo ya expuesto, nos propusieron considerar un orden racional que no iba más allá de sí mismo: la naturaleza racional no se trasciende a sí misma. El término 'racional' no pasa de ser un hecho más que está contingentemente en la razón humana y que la constituye. Sacaron partido de la palabra 'racional', que porta un prestigio, pero sólo designaba en ellos a una realidad como la lógica o la geometría. Actuaba una razón complaciente que se autocontemplaba suponiendo, sin más, una adecuación cognitiva entre ella misma y el resto de ella. De hecho, Locke indicaba que lo que él exponía era sólo una copia de su mente ${ }^{24}$.

Esta razón de cualidades tan amplias permitía no sólo hacer epistemología sino igualmente, filosofía práctica, como era la explicación de la justicia y el derecho. Pero, esta racionalidad, falta de un referente normativo, ¿cómo podía darse normas a sí misma? Los siglos XVII y XVIII desarrollaron juegos intelectuales en los que partían desde los hombres aislados en el estado de naturaleza (status naturae) y buscaban en la igual voluntad y libertad de estos hombres así imaginados la fuente para toda teoría ética y política. Es lamentable reconocerlo, pero hay que admitir que durante estos últimos cuatro siglos -salvando parte del siglo XIX- los nuevos teóricos de la justicia no han sabido salir de este círculo. El neocontractualismo anglosajón actual permanece preso en él. Propusieron lo que Kant llamó imperativos hipotéticos, que solamente comparten con las reglas que crean un deber el mismo nombre de 'imperativos'.

Desde el siglo XVIII a hoy los teóricos de la moral y el derecho se han encontrado frente a una mentalidad cada vez más fuerte. Sin entrar en precisiones, podemos llamarla 'materialismo'. Este tema, de acuerdo con lo que está publicado, es literalmente inmenso, y prefiero centrar el estudio en algún autor concreto, y ese autor concreto es en este caso Rudolph von Jhering, que oculta bastante en su Der Zweck im Recht y es más explícito en otros momentos. El momento al que atiendo ahora es preferentemente un breve artículo suyo aparecido en 1882 en los conocidos usualmente entonces como los Smöller's Fabrbücher.

24 LoCKE, J., «Essay of Human Understanding», en The Works of fohn Locke, London, 1823, vol. I, p. 12. 
Los materialistas del siglo XIX sentaban ante todo que sólo existe una protorrealidad que es reelaborada por diversas instancias y que nunca pierde su forma única y siempre misma para cambiar de naturaleza o cualidad. Jhering, siguiendo este carril ya tan transitado a la altura de 1882, nos dice que «La materia llama a la materia, porque sólo hay un progreso cuantitativo, no cualitativo» ${ }^{25}$. Sigue el lema, popular entonces, que enunciaba que «Todo es Uno. No hay una diversidad última $\gg^{26}$. Aquellos materialistas querían negar, a fin de cuentas, la diversidad de las cualidades, ya que entendían que esta multiplicidad llevaría a una visión ingenua de la 'materia' más allá de lo que ellos podían intuir. Es previsible que Jhering mantenga que la suya es una búsqueda de ciencia natural, una Naturforscbung ${ }^{27}$.

Él explica que el estudio del filósofo y el moralista es de índole psicológica, y el alma humana parte desde la psicología ${ }^{28}$. El estudio de la psicología muestra que el hombre es «un egoísta puro» ${ }^{29}$, y el secreto del éxito y de la colaboración social está en saber interesar a los demás en el propio egoísmo ${ }^{30}$. La realización conjunta de la mayor parte de los intereses forma el sistema social, ya que cada cual debe unir sus pretensiones a las de los otros: esto es el 'sistema' social ${ }^{31}$. Así se produce una lucha de intereses que conduce a la paz porque la fuerza queda sometida al derecho ${ }^{32}$.

La moral es creación social, ya que el individuo es únicamente una parte del todo ${ }^{33}$. No es obra de la naturaleza, sino de la historia; no es innata; en este punto ensalza encomiásticamente a Locke por haber rechazado las ideas innatas $^{34}$. La moral no es más que el egoísmo en su grado más alto: el egoísmo de la sociedad, porque el individuo comprende que sólo medra en ella. En modo alguno la moral se forma en el paso desde el animal al hombre ${ }^{35}$. Él en-

$25 \ll$ Stoff kommt zu Stoff hinzu, es ist ein Fortschrift in quantitativer, nicht in qualitativer Beziehung», JHERING, R., Die geschitlich-gesellschatliche Grundlagen der Ethik, «Jahrbuch für Gesetzgebung, Verwaltung und Volkswirtschaft» (Smoller's Jahrbücher) 6. Jahrgang, 1882, Erstes Heft.

26 Ludwig Knapp, explicaba que «Alles ist Eines. Es giebt keine letzte Verschiedenheit». KNAPP, L, System der Rechtsphilosophie, Erlangen, 1857, p 25.

27 JHERING, R., Die geschitlich-gesellschatliche..., op. cit., p. 18.

28 Ibid., p. 15.

29 JHERING, R., Der Zweck im Recht, Leipzig, 4ª ed., 1904, vol. II, p. 91.

30 «Die Egoismus in Dienste fremder Zwecke», ibid., p. 24.

31 Ibid., p. 43.

32 Ibid., p. 189.

33 JHERING, R., Die geschitlich-gesellschatliche..., op. cit., p. 5

34 Ibid., pp. 8 y 9.

35 Ibid., p. 7 
tiende que todas las normas de la moral tienden hacia el bien de la sociedad ${ }^{36}$, aunque patentemente se trata de un bien puramente pragmático, no deóntico. Ciertamente, hay dos tipos de morales, una social y otra individual, de corte kantiano; él prefiere atender a la moral social ${ }^{37}$, entre otras razones porque la moral está encargada de cuidar del bien de los ciudadanos ${ }^{38}$.

Es la doctrina del egoísmo 'juicioso' o razonable que, sin necesidad de recurrir a Mandeville, lo encontramos en tantas obras de los discípulos de Kant durante el período de finales del siglo XVIII y comienzos del siglo siguiente ${ }^{39}$. Ha sido el tipo de teoría que de hecho ha dominado a la Edad Contemporánea, que no ha sabido superar algún tipo de equilibrio entre el egoísmo individual y la universalidad de los efectos para todos (también para el infractor) si no sigue las reglas equilibrantes. Esto fue lo que propuso en definitiva Rousseau, y hoy lo renueva, con notable éxito de público, John Rawls.

\section{EL NUEVO 'DERECHO NATURAL'}

Desde el siglo XVII muchos han tratado que la justicia no sea un dato que esté dado, sino que haya que construir: parece indigno del hombre maduro admitir lo que ya hay en lugar de producirlo él. Toda fábrica es complicada (ya que no compleja normalmente), y ha sido preciso lanzar al gran público teorías realmente complicadas.

En este empeño, se detecta un primer problema, que consiste en que estas fábricas de teorías tratan a la moral -privada o pública, tanto da- como si fuera un todo unitario. Pero tratar a la ética personal o social 'en bloque', como si fuera un cuerpo físico único o inseparable, que se puede intuir en el espacio, supone entrar por un camino equivocado. En los seminarios desdeño esta posibilidad cuando alguno propone así el tema, porque hablando de este modo tan general sólo llegamos a discusiones interminables en las que todos tienen una parte de razón. Es preferible seguir la intuición de John Austin cuando explicaba que pertenece a la naturaleza de la moral el ser concreta ${ }^{40}$. Efectivamente, algunos profesores de Universidad discuten sobre la moral

36 Ibid., p. 6.

37 Ibidem.

38 Ibid., p. 7.

39 Carpintero, F., La Cabeza de fano, Universidad de Cádiz, 1989.

40 Austin, J., Lectures on furisprudence..., op. cit., p. 115. 
como si ella se pudiera expresar por un concepto abstracto y sostienen que no existe ninguna moral de alcance absoluto, sin embargo, están todos universalmente de acuerdo en que deben pagárseles sus sueldos con puntualidad.

Hace años se entendía que una ideología sólo podía ser combatida por otra ideología, lo que llevaba a un empate academicista. Aparece la razón de Habermas cuando explica, contra Luhmann, que para poder entender el plexo simbólicamente estructurado de los sistemas sociales como una constelación cuya facticidad descansa sobre pretensiones básicas, las cuales son tan susceptibles de crítica, es decir, tan atacables por la crítica, que necesitan de la inmunización cuando se las quiere sustraer a ella. Pero aplicada a su propia teoría, esta idea de Luhmann exige una autocomprensión ateórica de su propia teoría, es decir, su identificación inmediata con la acción ${ }^{41}$. Ahora, busco es comprensión ateórica, previa a la teoría, que resulta casi inmediatamente desde la acción, sabiendo que las intuiciones encajan en las formas universales de modos y maneras que desconocemos; la última palabra, incluso en el plano estricto de la física, la tiene la filosofía ${ }^{42}$.

Lo desdeñable es lo que describe Polaino, a saber, que el método científico se ha magnificado tanto -a través del 'monopolio científico excluyente' que practica- que no sólo informa de los datos obtenidos, sino de cómo hay que proceder para conocer, es decir, qué hay que conocer, qué valor tiene lo que se conoce, cuántos de los enunciados de sus teorías son inmodificables, cual es la estructura que es preciso satisfacer para que una teoría sea científica, etc.

Esta 'antropología implícita' de la que se parte supone -toda vez que se ha aceptado tal metafísica ${ }^{43}$ - la exclusión automática del sujeto. La paradoja resultante es que se 'desaloja' a la persona del contenido investigado -scientia

41 Habermas, J., La lógica de las ciencias sociales, trad. M. Jiménez Redondo, Tecnos, Madrid, 1988, p. 370 .

42 FrEY, G., La matematización de nuestro universo, trad. J. Barrio, Gregorio del Toro, Madrid, 1972, pp. 49 y 53.

43 La metafísica implícita en las teorías que pretenden rechazar la metafísica es un tema amplio. Yendo a uno de sus niveles más profundos, Massini nos informa que «La afirmación simultanea: i) de la cognoscibilidad veritativa de las exigencias de la justicia, y $i$ ) de la total independencia del derecho respecto de esas exigencias, conduce inevitable a una especie de esquizofrenia intelectual, según la cual existiría un deber estricto de obedecer un mandato que se reconoce objetivamente -con pretensiones de verdad- como grave y evidentemente inicuo. La realidad es que existe en el intelecto humano una exigencia intrínseca de unidad, un requerimiento de coherencia que transforma en irrealizable la pretensión de sostener dos afirmaciones que implican de un modo estricto una insalvable contradicción». MASSINI CORREAS, C. I., Constructivismo ético y justicia procedimental en Fohn Rawls, Unam, México, 2004, p. 67. 
sine bomo- al mismo tiempo que se le sustituye por el sujeto construido, que subyace agazapado en la particular 'antropología implícita' de cada investigador. La exclusión del sujeto singular -el núcleo de convicciones y rasgos de la personalidad que caracterizan unívocamente a cada ser humano como taltransforma a la persona en lo que ella no es: en una abstracción» ${ }^{44}$. Con razón indicaba Hegel que «He aquí por qué este concepto, como el conocimiento de la esencia, es algo encontrado de antemano, de lo que se parte y que cae dentro del sujeto filosófico» ${ }^{45}$. Efectivamente, hacemos teorías sobre la justicia porque ya creemos en la justicia.

Es difícil hablar de la persona, de la moral y de la justicia porque la ciencia de la Edad Moderna nos ha enseñado que desconocemos las causas últimas de las cosas y de sus movimientos. Esto ha generado un escepticismo casi universal. Pero frente a la universalidad inexplicada y quizá inexplicable, están las concreciones claras. Efectivamente, si prescindimos de las explicaciones de alcances universales, de ésas que quieren encontrar la justicia según el puesto del hombre en el Cosmos, el investigador confiesa que no tiene ideas claras sobre la naturaleza del tiempo y del espacio, sobre el Cosmos, o sobre qué es la moral, pero sabe con certeza que no debe molestar a sus vecinos. Hay un plexo de exigencias morales, compartidas por todos, anteriores a cualquier explicación de índole racional, que nos orientan continuamente, aunque fallen en algunos casos concretos. Pero estas confesiones nos introducen por un camino que de hecho es peligroso por desprestigiante, ya que parece que quién la sostenga defiende un cognitivismo ético, y en el siglo XX pocas realidades han estado más desprestigiadas que este tipo de conocimiento moral.

Tenemos una comprensión preteórica de la persona -que no es muy difícil encontrar fuera de las aulas universitarias- y disponemos del rechazo del método científico más tradicional, el newtoniano. Al no estar condicionados por este método y por sus variantes analíticas que han aparecido en el siglo XX, sabemos y afirmamos que el profesor debe explicarse con claridad, al menos con la claridad suficiente como para que le entiendan sus alumnos. Al

44 Polaino-Lorente, A., Antropología e investigación en las ciencias humanas, Unión Editorial, Madrid, 2010, pp. 48-49. El método científico quiere inordinar a los sujetos u objetos que estudia en series de notas cada vez más amplias: desde la especie al género, desde el género... Su meta última es la inmobilidad: inordinar a los objetos en series inalterables: ésta sería la mayor garantía de la cientificidad de la ciencia moderna.

45 Hegel, G.W.F., Lecciones sobre la historia de la filosofía, trad. de W. Roces, FCE, México, 1985, vol. III, p. 305. 
expresar «el profesor debe»... entramos por los campos de la moral universal, entre otras cosas -sin ser la única- porque el término profesor tiene una fuerte vertiente semántica.

La moral es el orden normativo que vive junto al derecho, en una convivencia que a veces es pacífica, a veces no lo es y con frecuencia es inadvertida ${ }^{46}$. Un buen sector de la opinión pública universitaria ha entendido recientemente, que ambos son dos órdenes de normas o reglas que coexisten de espaldas el uno al otro, de forma que solamente podría haber contactos tangenciales. Hoy, tras el éxito de las tesis de Dworkin, pocos mantendrían esto. Pero Dworkin es un hombre que, por las propias limitaciones que él se ha impuesto antes de comenzar el estudio, sólo conoce una versión light de la moral.

¿Cómo se ha podido producir este enfriamiento? Los siglos con que se inicia la Edad Moderna reclamaban un cambio social y político grande. Como no les servía, a este fin, el ius civile ni el ius gentium, recurrieron al tercer tipo del derecho reconocido entonces por el derecho romano, al ius naturale, que con el tiempo suplió a la moral y a buena parte de la teología. Era un problema de prestigio: se podía hablar con autoridad desde el alto derecho natural, pero no desde el anticuado ius civile. El tránsito desde el Ius Commune, que pretendía tratar simultáneamente al derecho natural, al de gentes y al civil, hasta la era de la Disciplina del Derecho Natural, fue confuso por atormentado. Pero, a lo largo del siglo XVI español las llamadas al derecho natural fueron imponiéndose en los libros eruditos, y sería todo un problema mantener si el «De justitia» de Luis de Molina o el «De legibus» de Suárez ${ }^{47}$ pretendían exponer derecho natural o únicamente eran unas reflexiones en tono general sobre el derecho y sus leyes, de modo que hicieron más bien lo que hoy llamaríamos filosofía del derecho. Lo mismo podemos decir de la obra más conocida de Hugo Grocio (1625, que no se atrevió a llamar a su obra Ius naturale) y fue Pufendorf, ya en época francamente tardía -cincuenta años después de Grocio- quién habló más claramente, titulando a su obra principal «Los ocho libros del derecho natural y de gentes». Es sintomático que en pocos años publicara un libro bastante extenso al que tituló simplemente «Elementos de jurisprudencia universal».

46 Este tema lo estudié más extensamente en CARPINTERo, F., Derecho y ontología jurídica, Actas, Madrid, 1993.

47 Suárez rechaza la metafísica y propone un conocimiento solamente modal. Pero esto no hace al caso porque subrayó con tal fuerza el orden modal que existe en la razón de todo hombre que él consiguió, quizá en mayor medida, lo que otros trataban de status mostrar según el conocimiento metafísico. 
Este jus naturale que se delinea tardíamente tuvo denominación de origen, por así decir, y se relacionó en muy poco con la 'idea eterna' del derecho natural. Pero hubo un dato importante: que, aunque la Edad Moderna desarrolló un saber nuevo, se quedó con el prestigio de la vieja expresión de 'derecho natural', que designaba un orden de bondad al margen de los avatares de la historia; unos contenidos nuevos que entraron en las Universidades de la mano de un rótulo viejo -que les servía de respaldo- especialmente prestigioso. De ahí la pasividad de los católicos, perplejos, que hasta la mitad del siglo XVIII permanecieron mudos frente a la avalancha de insultos y calumnias expuestas por los nuevos jusnaturalistas ${ }^{48}$. Sin duda, pensaban que, si alguien trataba el derecho natural, se insertaba en una tradición secular que sólo se compone de cosas buenas.

Si consideramos que Fernando Vázquez de Menchaca fue el primero que estableció los tópicos más básicos de este nuevo saber ${ }^{49}$, de él en adelante el derecho natural se caracterizaría por 'suponer' una vida humana al margen de la sociedad -vida en el status naturae-, plagada de carencias, de modo que los seres humanos habrían de desear, normativamente, hacer vida social: este tránsito desde el individuo aislado al coëtus social era una exigencia racional. Advirtamos un par de notas.

Una, que son únicamente los individuos los que se dirigen directamente hacia el único cuerpo social. La sociedad político-jurídica, formada únicamente por individuos, sería el primer grupo humano legitimado ante la razón. Esta tesis ya la había mantenido Luis de Molina ${ }^{50}$. ¿Y las familias, las ciudades, las órdenes religiosas, los gremios, etc.? Como estas doctrinas eran 'éticas de línea recta’ que sólo contemplaban a los individuos en tensión hacia su sociedad política, las llamadas 'sociedades intermedias' no tenían explicación desde este planteamiento. Hace notar Bertalanffy que, en esta visión del hombre, se requiere que no existan interacciones entre las partes y que las relaciones que describen el comportamiento entre estas partes sean unilineales ${ }^{51}$. Ya que

48 Vid. Carpintero, F., «La Modernidad jurídica y los católicos», en Anuario de Filosofía del Derecho, V (1988) pp. 383-412.

49 Vid. CARPINTERO, F., Del derecho natural medieval al derecho natural moderno: Fernando Vázquez de Menchaca, Universidad de Salamanca, 1977.

50 «Tunc est quoniam respublica ex familiis non constare, sed ex hominibus singulis». MoLINA, L., De justitia et jure opera omnia, Venetiis, 1614, Tract. II, disputatio. 23, col. 105.

51 BertalanfFy, L., Teoría general de los sistemas. Fundamentos, desarrollo, aplicaciones, trad. J. Almela, FCE, México, 1989, pp. 17-18. 
hablamos del 'mos arithmeticus seu geometricus' debieran haber quedado advertidos por una intuición muy elemental: que los números suponen siempre una multiplicidad lineal y unidimensional, por lo que se pueden representar en la «Recta Numérica $»^{52}$ en el caso de la ciencia del derecho. La homogeneidad impuesta a la fuerza y la linealidad como figura representativa del constructo que se estaba construyendo, hicieron estragos por su capacidad pedagógica ${ }^{53}$.

Estas 'sociedades' quedaron como residuos de un pasado irracional. ¿Eran consecuencias de necesidades argumentativas? No lo parece: todo científico sabe que toda la 'materia' que él estudia está dominada por la homogeneidad de lo medido, porque no se pueden comparar realidades heterogéneas, y los que quisieron ampararse en el prestigio de la matemática, de ahí el nombre de mos arithmeticus seu geometricus, extremaron esta homogeneidad. En realidad, en estas construcciones es difícil hablar de individuos, porque las relaciones han de ser las mismas para todos estos Sujetos-Objetos que sólo se identifican como datos relevantes por su índole igual. Esta analiticidad se paga con el precio de la uniformidad, ya que, si sólo existe una estructura axiomática, todos los objetos estudiados han de ser iguales ${ }^{54}$. Viene a la cabeza una idea muy presente: que una síntesis de esta naturaleza sólo puede tener lugar allí donde el análisis ha encontrado previamente un límite ${ }^{55}$. Fue un saber que nació

52 FreY, G., La matematización..., op. cit., p. 121.

53 Hace casi dos siglos William Whewell reparaba en que «Necessary truths are proved, like arithmetical sums, by adding together the portions of which consist. An inductive truth is proved, like the guess which answers a riddle, by its agreeing with the facts described... Demonstration is irresistible because all steps to the conclusion are exhibited, before we arrive at the conclusion... Deductive truths are the results of relations among our own thoughts». WHEWELL, W., The Philosophy of Inductive Sciences Founded upon Their History, London, 1847 (Reprint de Johnson, 1967), p. 23.

54 Estos jusnaturalistas ‘abstrajeron', en el sentido que este término tiene en las matemáticas. Couturat nos indica que la operación de abstraer exige un término común al que todas las magnitudes de una misma especie pueden referirse, y es por esta relación por lo que decimos que tales cosas son de una especie particular. Couturat, L., Les principes des Matémathiques. Avec un appendice sur la philosophie des Matémathiques de Kant, Paris, 1905; G. Olms, Hildesheim-New York, 1979, p. 102.

El desplazamiento de una figura cualquiera presupone la existencia de una serie de figuras congruentes. Pero si ya conocemos a la figura congruente, el desplazamiento es inútil. En realidad, el movimiento sólo sirve para mostrar la existencia o no de las figuras congruentes. Así, ibid., p. 191. Si ya conocemos las figuras congruentes, es decir, la posición original, etc., el razonamiento posterior se resuelve en pura analiticidad.

55 Saumells, R., La geometría euclídea como teoría del conocimiento, Rialp, Madrid, 1970, p. 79. Estos sistemas de ética siempre encontrarán el límite que señala Habermas: «Adorno nunca se hubiera atrevido a fabular sobre 'un nuevo sujeto' 'se refiere a un homo noumenon'. Lo que sí sabía era una cosa: que la libertad que fuera contraimagen polémica del dolor producido por las coac- 
entre muchas limitaciones establecidas voluntariamente y la pobreza humana garantizaba la esplendidez científica.

La otra nota sería la siguiente. A la irracionalidad del naturae se opone la racionalidad social. Esta 'racionalidad social' puede ser entendida en un sentido fuerte, como sería el de Hobbes y, especialmente, de Rousseau, y entonces habría que explicar que la única moral relevante ante el derecho es la moral creada socialmente, de forma voluntaria por el gobernante o dejando que hablen por sí mismos los intereses humanos. Las 'sociedades intermedias', cada una con su propio sentido de la justicia, de la caridad o de la moral, eran los peores enemigos de lo que consideraban la verdadera racionalidad moral y social. Pues cada sociedad posee sus propias exigencias morales: unas son las del padre con su familia, las del empresario con sus trabajadores, o las que existen entre los compañeros de trabajo, y otras son las que vivimos cotidianamente cuando andamos por la calle entre tantos desconocidos.

La Escuela del Derecho Natural Moderno acabó con este adelgazamiento provocado por la ética social. Era previsible esta desembocadura, porque las teorías que insistían en los derechos plurales de los hombres -la propiedad, la libertad y la igualdad- perdían de vista en exceso a la unidad. La sociedad política debía ser unitaria porque todos tendrán los mismos derechos, de forma que el desconocimiento del derecho de un solo individuo habría de provocar el crack de todo el sistema político. Esta nueva reductio ad unum hizo necesario exponer sistemas lógico-jurídico especialmente extensos y complicados.

\section{Los 'constructos' siempre iguales}

La primera tarea, realizada a comienzos del siglo XIX, fue la de negar la objetividad de un derecho natural o de una moral pretendidamente universal. Fue una época confusa, ya que rechazaron el derecho natural que ellos conocían y la mayor parte de sus ataques fueron dirigidos hacia la consideración de los sujetos aislados en el status naturae. Pero, junto con esta noción del ius naturale, rechazaron igualmente la que admite órdenes de justicia que en nada se relacionan con los individuos aislados y los 'estados de naturaleza'.

\footnotetext{
ciones sociales, no solamente tendría que superar la regresividad del pío del yo, sino también conservar su fuerza de resistencia contra la disociación en lo amorfo tanto de la propia naturaleza interna como de lo colectivo». HaBermas, J., Perfiles filosófico-políticos, trad. M. Jiménez Redondo, Taurus, Madrid, 1986, p. 155.
} 
Con el paso del tiempo, los constructos para defender las libertades de los hombres fueron entendidos como lo máximamente racional y, a más, como lo solo racional. En cambio, el hombre que ha ya optado en su vida y vive una libertad, ése ha traicionado la vocación liberadora de la reflexión sobre el derecho. El gran pecado es optar por lo concreto. Rawls opone siempre «la libertad como tal»-que es la que él propone-con las ideas religiosas, morales, políticas y jurídicas que ya existen, que están todas equivocadas $^{56}$. Como es comprensible, aparte de su rechazo de lo que ya existe, en ningún momento explica en qué consiste «la libertad como tal». Pero lo cierto es que los siglos XVIII y XIX habían elevado a la «Razón» a tal altura de prestigio, que toda teoría que partiera desde los individuos aislados, imponiendo un previo esquema hermenéutico, fuera trascendental o no, debía ser respetado.

Presentaron a la Razón como un Todo Unitario. Solamente podía haber una y la tesis tomista que mantiene que la razón no mide a las cosas, sino que ella se mide por las cosas que conoce ${ }^{57}$, Ratio non est mensura rerum sed potius e converso, no pudo ser entendida.

El dogmatismo de Rawls tiene una amplia tradición también dentro del modo de pensar liberal. Serna nos indica que Nino ha mostrado con toda contundencia que la moral social e histórica sólo tiene sentido a la luz de la moral ideal (u objetiva), pues quien profesa una determinada ética lo hace por considerar que los valores que la integran responden no sólo a su modo de pensar, sino que son en sí mismos valiosos, esto es, integran una moral ideal. En este sentido, todo aquel que argumenta sobre la justicia de un juicio moral está proponiendo «su personal justificación» (histórica, contingente, relativa al sistema moral que profesa), pero lo hace con la convicción de que tal justificación es la aportada por la moral ideal. Toda justificación moral postula

56 Este autor escribe que «Se afirman o profesan muchas doctrinas comprensivas razonables, y no todas pueden ser verdaderas (en realidad, ninguna de ellas puede ser verdadera)». RAWLS, J., Liberalismo politico, trad. S. R. Madero, FCE, México, 1996, p. 76. Se hacen realidad las palabras de Bergson: «L'intelligence est caractérisée par la puissance indéfinie de décomposer selon n'importe quelle loi et de recomponer en n'importe quel système». BERGSON, H., «L'évolution créatrice», en Euvres, PUF, Paris, $5^{\text {a }}$ ed., 1991, p. 628. Efectivamente, Rawls ha descompuesto y recompuesto lo que no es de su propiedad según leyes muy personales suyas.

57 «Ratio humana non est mensura rerum, sed potius e converso». Suma teológica, I-II, q. 91, art. 3 ad 2. Hablando del intelecto, explica que el mismo intelecto consiste en las species rerum que él conoce. Vid. Quaestiones Disputatae, Edizione Studio Domenicano, Bologna, 1992, q. 22, art. 11, resp. 
y exige, la referencia a unos principios únicos no justificables por otros, no relativos ${ }^{58}$.

Una gran ventaja retórica de los nuevos contractualismos es su homogeneización de las personas y, por ende, de sus relaciones: individuos iguales con las mismas necesidades. Desde estos presupuestos, el que se saliera de este marco de leyes debía ser considerado un insolidario o un irracional. El status naturae nunca ha existido realmente, y estos autores sabían esta inexistencia, pero eran conscientes de su éxito 'de público', tal como lo indica Habermas: «Una concordancia fáctica entre las hipótesis legaliformes deducidas y las regularidades empíricas es en principio contingente y permanece como tal externa a la teoría. Se considera inadmisible toda reflexión que no se conforme con eso... La indiferencia del sistema frente a su ámbito de aplicación se trueca en una falsificación del objeto. La estructura del objeto, preterida a favor de una metodología general, condena y torna irrelevante a la teoría en que esa estructura no puede penetrar» ${ }^{59}$. Porque el que se salga del marco impuesto por el procedimiento hegemónico en cada momento, sólo detectará problemas falsos, o cuestiones que no hacen al caso, o que pertenecen a otra asignatura. Debieran haber procedido, como sugería Bertalanffy, al descubrimiento de los principios de organización en sus diversos niveles ${ }^{60}$.

Ya que pretendían seguir un método analítico-sintético, yendo desde las partes al todo y desde el todo a las partes, como quería Hobbes ${ }^{61}$, debieran haber tenido en cuenta que, en la exteriorización externa de un desarrollo deductivo, lo formal no alcanza a fundamentar universalmente este desarrollo,

58 SERnA, P., Filosofía del derecho y paradigmas epistemológicos. De la crisis del positivismo a las teorías de la argumentación jurídica y sus problemas, Porrúa, México, 2006, pp. 128-129.

59 Habermas, J., La lógica de las ciencias sociales, op. cit., p. 23. Podemos ir más lejos en esta polémica. Un sistema es un «Todo» que posee sus propios axiomas, elementos functores y algoritmos, y si cumple el precepto de Hobbes, de poder ir desde el principio hasta el final, y desde el final hasta el principio, entonces está completo y clausurado. El único problema de esta exigencia es el que describe Bergson: desde el momento en el que él tiene que vincular el presente al pasado y prever el futuro, está obligado a abandonar esta posición central, colocar todas las imágenes en un mismo plano suponiendo que ellas sólo varían para sí mismas, y de tratarlas como si ellas formaran parte de un sistema donde cada cambio diera la medida exacta de su causa. La ciencia completa sólo es posible bajo esta condición. Así, BERGSON, H., «Matière et mémoire. Essai sur la relation du corps à l'esprit», en Euvres, PUF, Paris, $5^{\text {a }}$ ed., 1991, p. 177. Como se puede ver, la homogeneidad previa de lo considerado (lo aparentemente 'estudiado'), puesta por el investigador, es el verdadero quicio de estas teorías científicas.

60 BerTalanffy, L., Teoría general de los sistemas..., op. cit., p. 10.

61 Hobbes, T., Elements of Philosophy, London, 1839, p. 30. 
y cabría preguntarse si el momento formal puede producir algo por sí mismo. Nos interesa el «interior» o el «contenido» de la forma que, obviamente no puede ser pura forma. Pero su abundancia lógica, pretendidamente semántica, desconoció estas exigencias elementales. Prefirieron permanecer en ese momento de la ignorancia en el que se muestra que el proceder analítico de la ciencia clásica, con resolución en elementos componentes y causalidad lineal o unidireccional como categorías básicas, desconoce la investigación de totalidades organizadas por variables diversas que requieren nuevas categorías de interacción, transacción, organización, teleología, etc. ${ }^{62}$. Y si alguien pretende obtener normas desde la simple forma, habrá de demostrar cómo se hace eso, que los matemáticos aún no lo han logrado.

Por esto, su teoría social fue una filosofía del 'als ob' que creaba un constructo $^{63}$. Un constructo es un conjunto de axiomas y teoremas que pretende convertirse en el único cauce adecuado para lograr un conocimiento concreto, pero que con frecuencia -añaden sus críticos- tiende a erigirse en el canon universal y último de toda la ciencia. En estos procesos estará presenta la advertencia de Polaino: «Más en concreto, ¿dónde asienta el criterio de validez de las 'inferencias deductivas'? ¿Es qué medida una regla general de inducción está de acuerdo con determinada inferencia inductiva?... Se ha apelado a muy diversos criterios como la 'ley de la causación universal', la 'ley de la uniformidad de la Naturaleza', el principio de la continuidad espacio-temporal, etc., la mayoría de los cuales han sido rechazados». Sea como fuere, en el contexto de la investigación, las fases de observación y formulación de hipótesis parecen

62 Bertalanffy, L., Teoría general de los sistemas..., op. cit., Prólogo, p. XVI.

$63 \mathrm{Si}$ el lector quiere conocer la idea sobre los constructos que animan estas páginas, vid. CARPINTERO, F., La crisis del Estado en la Edad Posmoderna, Thomson-Aranzadi, Cizur Menor, 2012. Carpintero, F., Dogmas y escepticismo. Presupuestos de Filosofía del derecho, Escuela Libre de Derecho-Porrúa, México, 2013.

De una forma más limitada, CARPINTERO, F., «¿Regla de reconocimiento o contexto de reconocimiento?», en Ramos Pascua, J.A. y RodILLA, M. A. (ed.), El positivismo jurídico a examen. Estudios en homenaje a fosé Delgado Pinto, Universidad de Salamanca, 2006, pp. 171-195; CARPINTERO, F., «Reducir la complejidad: ¿hacia una razón esotérica», en Estudios en Homenaje al Prof. Andrés Ollero, Congreso de los Diputados, Universidad Rey Juan Carlos, Madrid, 2015, pp. 739-759; CARPINTERO, F., «Los constructos racionales en la reflexión sobre la justicia», en Dikaiosyne, 1. ${ }^{a}$ parte, 23 (2009) pp. 25-65, 2. ${ }^{a}$ parte, 24 (2010) pp. 59-87; CARPINTERo, F., «Métodos científicos y método del derecho: una historia superada», en Persona y Derecho 62 (2010/1) pp. 20-58; Carpintero, F., «Crisis de la ciencia, crisis del escepticismo ético», en Dikaion (Universidad de La Sabana, Colombia), pp. 11-52; CARPINTERO, F., «¿Pueden las teorías sobre la justicia sustituir a la doctrina de la ley natural?», en Persona y Derecho 66/67 (2012) pp. 315-352. 
estar más relacionadas con la inducción, y la verificación de las hipótesis, en cambio, que con la deducción ${ }^{64}$.

El juego conjunto del 'estado de naturaleza' y del pacto que ha de dar origen a la sociedad cumplía esta función. En realidad, esta construcción tan intelectual como artificiosa alcanzó un éxito impensable desde el siglo XVII, porque sus autores exigieron el estudio verdaderamente científico del ser humano (ellos lo llamaban natural), y entendieron que tal estudio sólo podía lograrse partiendo desde la consideración del hombre aislado. Este modo de ver al hombre y a su sociedad llegó hasta tal punto que los teólogos católicos del siglo XIX comenzaban sus tratados de derecho natural estudiando en primer lugar los derechos del hombre solitario, para tratar en el segundo momento el derecho del hombre que vive en sociedad. Antes, en el siglo XVIII, Schwarz, Finetti y Desing se habían rebelado contra la vena secularizadora del nuevo jus naturale ${ }^{65}$, pero en el siglo siguiente, en un ambiente académico de notable menos calidad, acogieron las figuras principales del enemigo que pretendían combatir ${ }^{66}$. Pues ni la Iglesia ni la familia, ni las órdenes religiosas o las agrupaciones de otra índole, encontraban acogida en estos esquemas más básicos ya aludidos; y los derechos de las personas para formar sociedades voluntariamente quedaban siempre bajo la sospecha de querer lograr intereses particulares o gremiales ('particulares' según los términos de Rousseau) bajo la capa de la libertad colectiva o del fomento del bien de todos. Sólo existía una razón, y por ello un solo bien verdadero, la volonté générale; la voluntad expresada en las votaciones, a la que despreciativamente llamaba la simple 'voluntad de todos', la volonté de tous, sólo reflejaba intereses concretos que, por definición, eran divergentes del único interés verdaderamente general. El pecado residía en lo concreto.

En cualquier caso, ya tratemos de un Estado más fuerte, o de un $R e-$ chtsstaat que tiene por misión proteger los tres derechos fundamentales del hombre -la libertad, la igualdad y la propiedad-, en esta nueva sociedad así diseñada no había lugar para otro orden normativo que no pudiera ser considerado necesariamente creación social. El Estado se convirtió en la instancia máxima protectora y creadora de los derechos sencillamente porque había de

64 Polaino-Lorente, A., Antropología e investigación..., op. cit., pp. 28-29. Su conclusión es que siempre está operativa una experiencia que actúa prerreflexivamente.

65 Sobre la escolástica de este momento es básico el estudio de Cabrera, L., Modernidad y Neoescolástica: Anselmo Desing, Universidad de Cádiz, 2001.

66 Vid. CARpintero, F., Fusticia y ley natural..., op. cit., pp. 381-410. 
ser la única. La lucha contra la antigua idea de la moral y contra cualquier posibilidad del derecho natural se convirtió en una tarea inexcusable del Estado $^{67}$.

Finalmente, casi todos dejaron de creer en una moral universal y en el derecho natural, y se pasaron a las filas de los defensores del Estado. Suponían que la Unidad que representaba el Estado era la primera condición del progreso. Un Estado en el que estuvieran vigentes el derecho legislado por el rey, el derecho canónico, el Ius Commune y los fueros y privilegios de las ciudades, fue visto como una realidad irracional. El nuevo Estado quiso una nueva moral cívica sobre la que reposa el derecho y, tal como Nino advertía, esta moral debía ser única.

Pero el Estado monopolista de la moral se reveló una realidad peligrosa en el siglo XX, y fue necesario establecer un nuevo orden que limitara sus poderes de una forma prácticamente idéntica a los libros de la Escuela del Derecho Natural Moderno. A este fin, la ONU lanzó en 1948 su Declaración Universal de los Derechos Humanos. Pero aquella Declaración estaba dominada por el espíritu de sus redactores, que eran por lo general agnósticos en la metafísica, en la religión y en la moral: dejaron un texto especialmente cualificado, pero era un simple texto, plagado de buenas intenciones, incapaz de generar un deber en las personas a las que iba dirigido. Ante esta insuficiencia, comenzaron a aparecer constructos sobre la justicia hechas por los mismos que negaban la objetividad de cualquier moral. Estas teorías sobre la justicia, ¿qué son, a fin de cuentas, se preguntaba James Bryce -él se refería a las Filosofías del derecho alemanas- sino sólo versiones del derecho natural? ${ }^{68}$.

Si prescinden de lo que el hombre es, es decir, de su vertiente metafísica -pensemos en el deber- o de su vertiente religiosa, resulta patente que aquellos derechos, que únicamente contemplan individuos solitarios, todos iguales, daban una presentación insuficiente de los momentos deónticos de la humanidad. La igualdad pude ser negada sin incurrir en compromisos, porque es una realidad intelectual entre aritmética y geométrica, pero ¿cómo arreglar el problema desde las bases mismas que han negado cualquier remedio? Porque

67 Vid. Carpintero, F., Los inicios del positivismo jurídico en Centroeuropa, Actas, Madrid, 1993. El lector puede encontrar otros datos sobre este mismo tema en la parte histórica de CARPINTERO, F., Una introducción a la ciencia jurídica, Civitas, Madrid, 1988.

68 BrycE, J., «The Methods of Legal Science», en Studies in History and Furisprudence, Clarendon Press, Oxford, 1901, vol. II. p. 173. 
la sola igualdad parece indicar ante todo las relaciones entre los ciudadanos y las leyes.

Estos últimos cuatro siglos nos han mostrado que cuando el hombre se aparta de su dimensión religiosa, es decir, desde el inicio de su razón práctica en Dios, el único recurso argumentativo que le queda, en el plano del deber, es el de hacer piruetas con alguna idea de la igualdad entre los individuos. Esto no es ninguna exageración. De todos modos, hay que advertir que éste es un tema de difícil tratamiento; ya Rudolph von Jhering nos indicaba que la revuelta de los moderni fue contra la Iglesia y después contra el orden establecido con el Naturrecht ${ }^{69}$. Massini comenta este hecho indicando que $«$ Si bien las dudas del positivismo acerca de su cognoscibilidad se refieren teóricamente a todas las propuestas morales, el objeto central contra el que se dirigen las impugnaciones resulta ser la moral cristiana y más especialmente la católica. Esto se puso en evidencia en la Conferencia de Bellagio, en donde se reunieron, entre otros, Herbert Hart, Alf Ross, Norberto Bobbio y Uberto Scarpelli para debatir acerca de la naturaleza del positivismo jurídico. En esa ocasión, al menos siete veces, según los cronistas del encuentro, se hizo referencia a que el positivismo jurídico debía considerarse como un valioso instrumento de lucha contra la moral católica ${ }^{70}$. Por su parte, la viuda de Herbet Hart no dudó en calificar a su marido como muy anticristiano, en un encuentro mantenido hace unos años con un investigador chileno ${ }^{71}$.

\section{LA MORAL Y EL DERECHO}

Podríamos hablar de dos planos en estas relaciones entre la moral y el derecho. Uno es el de las grandes influencias que afectan inmediatamente a la legislación. Es el caso del aborto provocado: si la ley nacional autoriza para abortar durante las primeras veinticuatro semanas del embarazo, esta permisión pasa inmediatamente al plano jurídico y de poco sirve, de hecho, argumentar que es inmoral.

El otro plano es más difícil de describir. Solamente podemos reconocer (reconocer, no establecer) que los 'índices' que dirigen la búsqueda del jurista

69 JHERING, R., Der Zweck..., op. cit., vol. II, p. 135.

70 Falk, R. A. y SChuman, S. I., «The Bellagio Conference on Legal Positivism», Fournal of Legal Education, n. ${ }^{\circ} 14$ (1961), pp. 213-228

71 Massini Correas, C. I., Constructivismo ético..., op. cit., p. 68. 
y del juez son con frecuencia morales. Y que las normas seleccionadas son 'encontradas' al filo de razonamientos que están guiados por consideraciones que también, frecuentemente, disponen de apoyaturas de índole moral ${ }^{72}$. De ahí que, frente al mos geometricus tan pretendidamente científico, Johann Eisenhart publicara ya en 1726 un estudio que tituló «Comentario sobre el uso de los principios de la filosofía moral al crear y al aplicar el derecho civil» ${ }^{73}$. Pero su obra recayó un altum silentium en un momento que detestaba todo lo que pudiera suponer el reconocimiento de una moral de alcance universal. Para el positivismo era más atractiva la opción de C. S. Nino, de la que Serna explica que también desde la filosofía analítica del lenguaje ordinario se ha acogido esta ampliación de la perspectiva, aunque sin aceptarla en todas sus consecuencias. Así, Nino reconoce la conexión justificadora entre la moral y el derecho, en el plano de las razones para la acción, que se prolonga por ello mismo, de modo necesario, como conexión interpretativa en el momento de las decisiones judiciales; pero se niega a admitir que ello, por más que resulte inevitable, conduzca a la necesidad de reconocer una conexión conceptual entre ambos órdenes normativos ${ }^{74}$.

Esta imbricación de las reglas morales en las jurídicas la mostró de una forma abrumadora con su aportación de datos, y con un razonamiento de pulso magistral, Josef Esser con su «Principio y norma»; pero se adelantó a su tiempo y, de todos modos, no hubiera tenido éxito en nuestro tiempo de moral light. De hecho, él mismo se vio tan acosado por sus compañeros de claustro que publicó, algunos años después, su «Vorverständing und Methodenwahl in der Rechstfindung», obra en la que se adhirió a la ligereza que reclamaban los tiempos.

El planteamiento más usual hoy, después del impacto del Positivismo Legal Incluyente, es relacionar los principios morales con el derecho. Si desechamos esta nueva versión del ¿positivismo? hemos de ir al planteamiento más usual en los años '60 y '70 del siglo pasado, cuando nos preguntábamos

72 Se manifiesta la verdad de la tesis encerrada en las explicaciones de Eisenhart. Pedro Serna, comentando a Josef Esser, habla frecuentemente de recurrir a juicios valorativos, conscientes o inconscientes, de índole política o moral... habría que aceptar que los confines del derecho se han trazado mal, que el derecho no se reduce al sistema normativo, que la realidad de este último es porosa, y que en la práctica no cabe trazar una separación radical entre el sistema de normas positivas, que sería el derecho, y el conjunto de las valoraciones que intervienen en su operatividad. SERNA, P., Filosofía del derecho..., op. cit., p. 42.

73 EISENHART, J., De usu principiorum moralis philosophiae in jure civili condendo et interpretando Commentarius, Helmstadt, 1726.

74 SERna, P., Filosofía del derecho..., op. cit., pp. 43-44. 
por qué el derecho era y había de ser algo más que una sanción socialmente organizada.

Nadie duda de que las normas que dicta el Parlamento y las sentencias de los Tribunales han de contar con un cauce final y procedimental coactivo. No basta cualquier procedimiento: el cauce ha de ser sancionatorio de alguna forma y ha de estar institucionalizado legalmente. La sociedad tiene establecidos también diversos modos para premiar o castigar, y a veces estos premios y castigos que viven al margen del derecho pueden ser más buscados, o más evitados, que los previstos institucionalmente en las leyes. Pero en este punto la vida social discurre paralela a la del derecho. Las sanciones jurídicas y sociales tienen en común una cierta racionalidad pero, a pesar de esto y por diversos motivos, es la única y misma sociedad en ambos casos la que decide lo que será derecho y lo que quedará en manos de los simples usos sociales.

Pero decir que el derecho dispone de un procedimiento final que tratará de aplicar una coerción implica una ingenuidad notable. Hay derechos y deberes que están claros, aunque los representantes de las corrientes hermenéuticas se empeñen en problematizar toda la vida jurídica; y hay con frecuencia derechos y deberes que distan de estar claros, aunque los enemigos de la hermenéutica se empeñen en simplificar el proceso aparentemente sólo aplicador de las reglas jurídicas. Pues a veces el derecho es como la lluvia, que sólo vive cuando muere, y por esto el diálogo sobre él es interminable. Esto lo hacía notar ya en 1912 un buen conocedor del derecho, como era Erich Danz ${ }^{75}$, y en este mismo año refrescaba el problema Philip Heck -antes de convertirse en fervoroso partidario de la Interessenjurisprudenz-, con su «Das Problem der Rechtsgewinnung» ${ }^{76}$.

El problema hermenéutico puede ser un buen punto para volver a estas consideraciones. Es, al menos en un primer momento, el que introduce el Caballo de Troya en el interior de las corrientes que han entendido que el derecho se compone de normas que están claramente establecidas, con tanta claridad al menos como permite el idioma: recordemos a Hart cuando sólo reconocía la 'textura abierta' propia de cualquier comunicación. Para los positivistas de primera hora, tales como Knapp o Bergbohm el derecho establecido (positivo) era un hecho tangible, recogido en los libros legales: no podía ser especialmente confuso ni tener lagunas. Trataron al derecho como si fuera un cuerpo ubicado en el espacio, del que debieran ocuparse las ciencias natu-

75 Danz, E., Richterrecht, Carl Heymann, Berlin, 1912.

76 Heck, P., Geblen, Bad Homburg vor der Höhe-Berlin-Zürich, 1968 (1912) 
rales $^{77}$ : no puede haber lagunas porque así como una casa es una casa y tiene unos límites precisos, sin que pueda hablarse de casas incompletas o del no-ser de ellas, el derecho está-ahí sin que haya nada antes o más allá de él ${ }^{78}$.

\section{El DEBER INESQUivabLE}

¿Por qué ha de ser obedecido el derecho? Para no dar pie a ilusiones me apoyaré en Frederick Harrison, que entendía que este tema era el más difícil de toda la reflexión jurídica ${ }^{79}$. ¿Qué es el derecho si prescindimos del deber de ser obedecido?

La tendencia a pensar según esquemas geométricos puede llevar a disociar ambos 'cuerpos' normativos porque no en vano Bergson destacaba que la geometría es la metafísica natural de la razón humana ${ }^{80}$. Ya indiqué que, para ellos, el conocimiento del derecho era un proceso similar al de la intuición de los cuerpos en el espacio: el derecho es un cuerpo y la moral otro, y son conocidos mediante actos distintos. En esta mentalidad no hay problemas humanos o morales en el derecho, esto es, problemas que sean relevantes también en sede jurídica. Sucedía que para ellos las leyes, por el hecho de existir, son derecho, han de ser cumplidas y no tiene sentido plantearse, desde el seno mismo del derecho, la cuestión del deber de cumplirlas.

En esta empresa, quién más ayudó expresamente fue Immanuel Kant. En la primera parte de su «Crítica de la razón pura», a la que llamó «Doctrina de

77 Bergbohm, C., Furisprudenz und Rechtsphilosophie. Leipzig, 1882. KNAPp, L., System der Rechtsphilosophie, Erlangen, 1857, ya había puesto las bases fundamentales de esta actitud metódica. Si queremos señalar un hito intermedio, tenemos el breve estudio de JHERING, R., Die geschitlich-gesellschatliche..., op. cit. En este estudio explicita resumidamente lo que no quiso expresar en su estudio sobre el fin en el derecho.

78 Laband y Brinz entendieron que el Derecho positivo no tiene lagunas. Para ellos, lo no-regulado es simple vacío jurídico. También así BergBoHm, furisprudenz und Rechtsphilosophie, op. cit., p. 372. Fue Ernst Zitelmann, en sus estudios sobre el código civil alemán, el primero que mostró que existen regulaciones necesariamente incompletas.

79 Harrison, F., On Furisprudence and the Conflicts on Law, Oxford, 1910, pp. 24-25.

80 En realidad, esta tesis ha sido compartida más ampliamente, Ferdinand Gonseth entendía que la geometría «Elle porte en elle, disons-nous-déjà, la structure de notre organisation mentale». GONSETH, F., La géometrie et la problème de l'espace, Dunond Éditeur, Paris, Éditions du GriffonNeuchâtel, 1955, p. 522. Bergson había dejado establecido que «Creer que los cuerpos vivos pueden ser estudiados como el sistema solar, matemáticamente, ésta es una cierta metafísica desarrollada tras los descubrimientos de Galileo, pero que verdaderamente es la metafísica natural del espíritu humano. Bergson, H., «Matière et mémoire...», op. cit., p. 511. 
los elementos», distinguió los fenómenos de la sensibilidad de los 'conceptos' que el psiquismo humano forma con ellos, de modo que, al final del proceso de fusión entre los fenómenos y los principios puros a priori que aporta el Verstand humano, obtenemos unos conceptos que nos impiden conocer lo que la cosa es en sí misma. Algunos han entendido que Kant niega el conocimiento no sólo de los objetos en el espacio (cuestión de la Mecánica) sino también los procesos más humanos. Esto es un grave error, y el mismo nos amonesta cuando indica que «El concepto de derecho, del que el entendimiento sano hace uso, contiene indudablemente todo lo que la especulación más sutil es capaz de desarrollar a partir de él, pero en el uso común y práctico no se tiene conciencia de las diversas representaciones incluidas en este pensamiento. Por ello no puede decirse que el concepto común sea sensible ni que contenga un mero fenómeno, ya que el derecho no puede manifestarse, sino que tenemos su concepto en el entendimiento y representa una propiedad (la propiedad moral) de las acciones, una propiedad que pertenece a éstas en sí mismas. Por el contrario, la representación de un cuerpo en la intuición no contiene absolutamente nada que pueda pertenecer a un objeto en sí mismo, sino simplemente el fenómeno de algo y el modo según el cual ese algo nos afecta. Esta receptividad de nuestra facultad cognoscitiva se llama sensibilidad y es completamente distinta del conocimiento del objeto en sí mismo, aún en el caso de que pudiera penetrarse hasta el fondo de dicho fenómeno» ${ }^{81}$.

Esta advertencia cayó en el vacío. Tengamos presente la pobreza filosófica del momento. James Lorimer advertía a sus lectores -en una de las obras sobre furisprudence más leídas en el siglo XIX inglés- de la penuria filosófica existente hacia $1888^{82}$. Era necesario improvisar sobre la marcha los fundamentos de los propios razonamientos. Para los autores progresistas de aquel momento, que eran materialistas (los positivistas solían declararse materialistas), era imposible recurrir a una noción metafísica como es la del derecho o la del deber ${ }^{83}$. Para ellos la marcha del mundo, también el mundo humano, se

81 KanT. I., Crítica de la razón pura, trad. P. Ribas, Alfaguara, Madrid, 1988, A43-A44.

82 LORIMER, J., The Institutes of Law, $2^{\mathrm{a}}$ ed., Edinburgh, 1880, p. 40

83 Esta tendencia comenzó muy pronto, en los inicios en la Modernidad. Vid. CarpinTero, F., «Deber y fuerza: la Modernidad y el tema del deber jurídico», en Obligatoriedad y derecho. XII Fornadas de Filosofía furídica y Social, Universidad de Oviedo, 1991, pp. 151-182.

Francisco Suárez, hacia 1610, ya detectaba la operatividad de los que querían prescindir del deber en la aplicación del derecho, y dejó establecido que «Nulla poena sine culpa». SuÁREz, F., Tractatus de legibus..., op. cit., L. V, cap. 3, \$3. 
resolvía en una simple sucesión de causas eficientes, a la que llamaban el 'movimiento'. Desde este presupuesto no había espacio para hablar de libertad o moralidad, pero esta visión del mundo no les planteaba problemas porque entonces aún era fuerte la inercia de la tradición moral cristiana y casi todos estaban de acuerdo en lo fundamental; por esto se permitieron el lujo de negar la validez de la filosofía práctica en la génesis y aplicación de las normas jurídicas.

Kelsen publicó en los años '20 del siglo pasado sus «Hautprobleme», una obra en la que, entre otros temas, trae un extenso tratado histórico, centrado en el siglo XIX alemán, sobre la noción del deber de cumplir el derecho en los principales autores del siglo anterior. El resultado de su investigación fue desolador: aparte de algunos que aún mantenían un ingenuo contractualismo, como Binding, los autores más conocidos del siglo XIX evitaron estudiar este tema. No en vano era insoluble por la razón indicada, y viene en nuestra ayuda el testimonio de John Austin, que había indicado que Hobbes había propuesto como un deber religioso de la obediencia ${ }^{84}$, y la figura del contrato quedaba excesivamente pequeña y desproporcionada para la empresa a la que se la requería. Por lo general, los que aludieron a este problema entendían que, si existía una sanción ligada al supuesto de hecho previsto en una ley, ya existía el 'deber' jurídico: era la misma respuesta que había dado el derecho natural moderno ${ }^{85}$. La historia del razonamiento secularizado se reitera sobre sí misma. Un tema que tiene importancia porque, como indicaba Clark, el deber jurídico es imprescindible allí donde hay sujetos morales ${ }^{86}$.

Para los positivistas de segunda generación como Kelsen, el problema de los contenidos del derecho no es tal porque cada órgano administrativo superior 'habilita' (él hablaba de Berechtigung) a los órganos administrativos inferiores para crear derecho. El derecho es un ordenamiento dinámico porque, a diferencia de la moral, los contenidos de las normas jurídicas superiores no determinan los contenidos de las normas inferiores. Dicho sea incidentalmente, Kelsen, que ocupó cargos en el Ministerio austríaco para la legislación, no pareció pensar en el derecho privado: quedó preso en lo que los alemanes llaman el 'Staatsrecht', que es una combinación de lo que hoy llamamos derecho político y derecho administrativo. La razón práctica no era tema que tuviera

84 Austin, J., Lectures on furisprudence..., op. cit., p. 280. Nota a pie.

85 Vid. Carpintero, F., «Imputatio», en Rivista Internazionale di Filosofia del Diritto, LXXXI (2004), pp. 25-78.

86 Clark, E. C., Practical furisprudence. A Comment of Austin, Cambridge University Press, 1883, p. 117. 
reconocimiento en su Teoría Pura del Derecho. ¿Por qué deben ser obedecidos los contenidos de las leyes? Él no creía en una moral de validez objetiva y, en la segunda edición de su Reine Rechtslehre (Wien, 1960) alegó algunas enseñanzas de Cristo -que él suponía contradictorias- acerca de la relatividad de la moral que se desprende desde estas incoherencias cristianas. Tampoco creía en los contractualismos. Para él el derecho obliga porque existe un sector de la realidad social que captamos bajo la categoría pura a priori del Deber-ser, $S_{0}-$ llen, a diferencia de la realidad que estudian los sociólogos, que sólo pertenece al mundo del Ser o $\mathrm{Sein}^{87}$. La noción del deber resultaba analítica: conocemos lo que deber ser precisamente porque eso que hay es lo que debe ser.

De este modo, Kelsen sustituyó el estudio de las necesidades humanas por el estudio exclusivo de las normas: las nociones de persona, derecho o nación resultaban desde las normas. Sin embargo, lo cierto es que su teoría 'pura' no lo es tanto, pues él rastrea las normatividades más fuertes en la sociedad y retiene como jurídica la dominante en mayor medida. Ésta es el alma de la Norma Hipotética o Grundnorm. Aparte de esto había que cuestionar si Kelsen era un escéptico en los temas morales ${ }^{88}$.

En 1960 emergió la obra más conocida de Hart, que distingue brillantemente, desde un punto de vista lógico y literario, entre reglas primarias de obligación y reglas secundarias que capacitan para legislar o para juzgar ${ }^{89}$. Con él entramos en lo que podemos llamar positivismo de tercera legislación. Pero tropezó con el problema de la moral o de la racionalidad práctica porque -es una cuestión que se plantea él mismo- ¿pueden ser llamadas leyes muchas de

87 Kelsen, H., Reine Rechtslebre, Frank Deuticke, Wien, 1960. Algunas exposiciones más sintéticas en Kelsen-Cossio, Problemas escogidos de la Teoría Pura del Derecho, Guillermo Kraft Limitada, trad. de C. Cossio, Buenos Aires, 1952, cap. 1.

88 El investigador tiene la impresión de que sus explicaciones sobre el carácter dinámico del ordenamiento jurídico surgieron desde la necesidad que apreciaron varios estudiosos de lengua alemana de finales del siglo XIX de luchar contra la 'dictadura' del Káiser. Una lucha en la que participó Kelsen porque era de ideas liberales. Mientras que Laband, Otto Mayer o Nawiasky proponían explicaciones que no prejuzgaban la necesidad de algún límite al poder político, Georg Jellinek, Adolf Merkl y Hans Kelsen vieron este tema de forma distinta. Jellinek se lanzó por un camino decididamente jusnaturalista.

Merkl hizo reflexiones normalmente desde el interior de la dogmática conceptual propia del Staatsrecht de la época. Kelsen quiso recortar el poder del Gobierno mediante su teoría de los ordenamientos de contenidos dinámicos; fue significativo que, aunque mostró una fuerte madurez universitaria en los años '20 -pensemos en sus Hauptprobleme- no publicó la primera versión de su Reine Rechtslebre hasta 1934, cuando el partido nazi llevaba dos años instalado en el poder.

89 HART, H.L.A., El concepto del derecho, trad. Genaro R. Carrió, Abeledo-Perrot, Buenos Aires, 1961, pp. 99-124. 
las disposiciones de los nazis? Él afirmó que son verdaderas leyes, pero que «son demasiado inicuas para ser obedecidas $»^{90}$. Esta cuestión nos introduce en el corazón del problema que ocupa estas páginas. La razón es bien sencilla: toda ley es una pretensión de obediencia, y si una ley no 'debe' ser obedecida... Un escolástico, o un buen conocedor de la filosofía clásica como Heidegger, diría que aquí hay una circulatio. No un círculo de naturaleza lógica sino una contradicción vital que no pueden soportar los seres humanos.

El deber es una realidad metafísica, igual que la noción de persona, porque no es perceptible por los sentidos ni puede ser deducida desde un conjunto axiomático: estas realidades son más bien los axiomas desde los que hay que partir, no el resultado de los razonamientos. El problema del deber es recurrente en todo este tema y es lo que constituye el corazón de toda Filosofía del derecho.

Para comprobar la imposibilidad de desconocerlo, tomemos como referencia a un legislador cualquiera que diga ser agnóstico, materialista, o como él quiera expresarse. (Una persona así no puede reconocer la existencia de una realidad metafísica como es el deber). Ese legislador, ¿puede decir a sus súbditos: «Conciudadanos, os daremos unas normas que no tenéis el deber de obedecer»? Ciertamente, el derecho necesita de la coerción pero no se resuelve en coercibilidad socialmente organizada. Quienes pierden de vista este hecho lo hacen porque han caído bajo una falacia muy vieja, a saber, que sustituir lo uno por lo otro es una posibilidad común a todo lo compenetrable, y el deber de hecho de cumplir las normas es absolutamente compenetrable con su naturaleza coactiva.

Ante éste y otros problemas ha aparecido una cuarta generación de positivistas que se llaman a sí mismos integrantes del Positivismo Jurídico Incluyente $^{91}$. A Bergbohm, Kelsen o Hart se les puede llamar positivistas por su amor al derecho 'ya' claramente establecido. Pero, si para hacer justicia y cumplir con el deber, establecen la operatividad de una multitud de principios

90 Este tema del condicionamiento de la validez del derecho por la moral, provocó mucha literatura. Un estudio recomendable es el RAMOS PASCUA, J.A., «Balance crítico de la filosofía jurídica de H. L. A. Hart», en Dikaiosyne (enero-junio del 2009), pp. 131-144.

91 Me refiero a esta corriente tal como la representa, de una forma especialmente didáctica, WALuchow, W.J., Positivismo Furídico Incluyente, trad. de M. S. Gil y R. Tesona, Marcial Pons, Madrid, 2007. Una presentación bastante clásica fue la de Mora Sifuentes, Carlos III, Madrid, 2010. Una propuesta que fue criticada en ETCHeberry, J.B., «El ocaso del Positivismo Jurídico Incluyente», Persona y Derecho, 2012, vol. 67, pp. 411-447. 
divergentes, e incluso opuestos, que pueden encontrar todos acomodo en el ordenamiento jurídico, sin que los ciudadanos sepan anticipadamente cuáles serán los aplicables, no verifican la definición del positivismo en el derecho, y si se quieren llamar positivistas esto sucede, como ha destacado Serna, por algún motivo emocional que poco tiene que ver con los estudios pretendidamente racionales que hacemos en las Universidades ${ }^{92}$.

Este motivo está en las profundidades de la consciencia personal y muy frecuentemente tiene un cariz entre religioso o moral (moral de principios) ${ }^{93}$. Los seguidores del espíritu de Pufendorf-no así los de Grocio- bien redujeron el deber al hecho de estar previsto un castigo para el caso del incumplimiento de la norma, bien al miedo psicológico hacia ese castigo. Samuel Cocceius les indicó que no existe deber porque se imponga un castigo sino que se impone un castigo porque se ha incumplido antes un deber $^{94}$, recordándoles, como había hecho Francisco Suárez un siglo antes, que Nulla poena sine culpa $a^{95}$. Había sucedido un hecho extraño. Luis de Molina, de una forma muy poco matizada,

92 Serna escribe que «Si tal objetivo compatibilizador se alcanza, será a fuerza de acabar llamando positivismo a algo diferente de lo que era considerado tal antes de la redefinición». SERNA, P., Filosofía del derecho..., op. cit., p. 55. Esa insuficiente justificación es inevitable: no se trata de que Alexy no la ofrezca de hecho, sino que no la puede ofrecer. Las R del discurso no pueden ser justificadas por el discurso. En una racionalidad discursiva, el discurso puede ser $\mathrm{O}$ del discurso... pero entonces surge la pregunta de si el discurso acerca del discurso es un discurso racional, al, si se adapta a las reglas del discurso. Ibid., p. 91.

93 Vid. Carpintero, F., «Deber y fuerza...», op. cit., pp. 151-182.

94 Así se expresaba CoCCEIUS, S., Tractatus juris gentium de principio juris naturalis unico, vero et adaequato, Francofurti ad Moenum, 1702, p. 25. Cocceius fue un autor importante, aunque hoy está prácticamente en el olvido. Bastantes jusnaturalistas del siglo XVIII entendían que Grocio, Hobbes, Pufendorf, Cumberland y Cocceius habían sido los tratadistas del derecho natural más importantes hasta entonces. Vid., por ejemplo, a Schмаuв, J.J., Neues Systema des Recht der Natur, Göttingen, 1754, 2. ${ }^{\text {a }}$ parte, Dubia juris naturae, pp. 404-405.

El de Cocceius fue un caso interesante. Él fue un autor muy peculiar. Logró que sus ediciones del «De iure belli ac pacis» de Grocio, comentadas profusamente por él mismo, fueran las más editadas y leídas. Sin embargo, Cocceius no es propiamente un iusnaturalista moderno: fue uno de sus máximos impugnadores, junto con Gaspar Ziegler. Cocceius es un jurista de mentalidad tradicional, romanista, con una formación teológica más próxima a Tomás de Aquino que no a los protestantes, que sin embargo tuvo la habilidad de pasar por iusnaturalista moderno, y de ahí el éxito de sus comentarios a Grocio.

B.Chr.Fr. Schott publicó en 1784, en Erlangen, sus Dissertationes iuris naturalis. Se trata de relectiones que él había dado a partir del año 1753. Los dos volúmenes de estas Dissertationes constituyen unas de las obras de Filosofía del Derecho más interesantes del siglo XVIII, y presenta la peculiaridad respecto de otros coetáneos que Schott sí se preocupa explícita y extensamente de tratar el tema del deber jurídico.

95 SuÁREZ, F., Tractatus de legibus..., op. cit., L. V, cap. $3, \S 3$. 
había reducido el fundamento del derecho, también el del derecho penal, a pactos entre los ciudadanos ${ }^{96}$. Debió tener éxito doctrinal porque Hugo Grocio, de ordinario tan mesurado, hizo lo mismo ${ }^{97}$. Francisco Suárez reaccionó contra estas opiniones.

Pero estas advertencias racionales tropezaban con sentimientos secularizadores que habían de ser impuestos a toda costa. De ahí el estudio, ya citado, sobre la negación de la realidad del deber desde el siglo XVII.

\section{UNA REACCIÓN HISTÓRICA}

Siempre es apasionante el estudio del paso del siglo XVIII al XIX, es decir, del Antiguo Régimen al Estado, y a este tema dediqué dos monografías, una centrada en los discípulos de Kant y otra sobre los inicios de la mentalidad positivista, en el derecho en los territorios de lengua alemana ${ }^{98}$. El gran tema común del pensamiento político-jurídico de comienzos del siglo XIX fue la creación del Estado. El Antiguo Régimen se había agotado vitalmente y esta nueva generación buscó una redención colectica a través de las actividades políticas para hacer realidad la idea del Estado con su afán de unidad, en el que pusieron sus esperanzas. Exactamente, no buscó mejorar sus condiciones de vida: buscó más, porque quiso un hombre nuevo que sustituyera al hombre sin vitalidad que conocían entonces. Es obvio que la lucha por la imposición del Estado tuvo un cierto carácter escatológico, al menos en algunos sectores cultos.

En este tema se dividieron los 'jusnaturalistas' modernos. Si nos ceñimos al siglo XVIII, vemos que los 'más juristas', como fueron Wolff, Daries, Burla-

96 «Judicem, et quem ius dicit in civilibus, et quem causas tractat criminales, poenam justam inflingit... quasi ex pacto cum Republica». Molina, L., De justitia et jure..., op. cit., Tract. II, disp. 12.

97 Anselm Feuerbach indicaba que «Grotius der längst vergessene und unter dem Staub der Bibliotheken modernde Grotius scheint mir daher den wahren Grund des Strafrechts weit richtiger und klärer eingesehen zu haben, weningstens der Wahrheit um ein Grosses näher gekommen zu seyn, als gar viele unserer neuer und sonst gründlich philosophierende Rechtsgelehrten. 'In hanc re, sagt er, est aliquid quo ad contractum naturam accedit: quia, sicut qui vendit, etiamsi nihil peculiariter dicat, obligasse se videtur ad ea omnia que venditionis sunt naturalia, ita qui deliquit sua voluntate se obligasse videtur poenae, quia crimen non potest non esse punibile; ita ut qui directe vult peccare, per consequentiam et poenam mereri voluerit'». D.J. ac P. L. II, c. XX, 2, n. 1. Anti-Hobbes oder über die Grenzen der höchsten Gewalt und das Zwangsrecht der Bürger gegen das Oberherrn, Erfurt 1798, p. 224. Esta vez, Grocio no citó la fuente de esta tesis suya. Se encuentra en la obra citada de Molina, Tract. II, disp. 12.

98 Sobre los discípulos de Kant, Carpintero, F., La Cabeza de fano; ID., Los inicios del positivismo jurídico en Centroeuropa, Actas, Madrid, 1993. 
machi, Heineccius o Nettelbladt, expusieron códigos de derecho natural, que solían consistir en un derecho romano más o menos idealizado. Algunos de ellos, como Daniel Nettelbladt, fueron personas especialmente conservadoras para los aires del 1700, y lo mismo podemos decir de Burlamachi.

Pero hay otra afectividad, que cuaja en otra línea de pensamiento que operó más soterradamente, y que fue la revolucionaria. Grocio y Pufendorf fueron autores moderados que en modo alguno superaron la radicalidad de los españoles inmediatamente anteriores. En otra línea de pensamiento, Frederic Harrison entendía que Austin remató a Hobbes ${ }^{99}$ y que Hugo Grocio ha de ser considerado el gran enemigo del derecho natural hasta Bentham ${ }^{100}$. En un sentido distinto, Lightwood explicaba que había habido dos direcciones dentro de la furisprudence, la del derecho natural y la de la de Bentham ${ }^{101}$. Como puede observar el lector, estamos ante una feria de confusiones.

Una vez que el Parlamento de París ordenó la retirada de los libros españoles, representados entonces en el tratado sobre la educación del Rey de Juan de Mariana ${ }^{102}$, la reflexión política entró por un camino francamente conservador. Los nuevos libros que hablaban de los derechos del hombre infundían miedo a las autoridades, pero guardaban las formas. Rousseau fue uno de los pocos que, fundamentado en su prestigio como pedagogo y como filósofo, irrumpió en este proceso con una fuerza que se avenía mal a las restricciones monárquicas de entonces. Él se muestra más bien apasionado, pero la mayor parte de las denuncias que hace sobre los hombres de su momento, podrían haber sido suscritas por un moralista usual que poseyera una visión catastrofista del momento que le había tocado vivir.

Finalmente se mostró en la vida política práctica la línea de pensamiento que arranca de Hobbes y de Locke, y la Revolución de 1789 mostró este

\footnotetext{
99 Harrison, F., On Furisprudence and the Conflicts..., op. cit., p. 14.

100 Ibidem.

${ }^{101}$ LightwOOD, J.M., The Nature of Positive Law, London, 1883, p. 58.

102 Juan de Mariana publicó un estudio sobre la formación que había de recibir el futuro Rey. Sus planes de estudios giraban en torno a las Humanidades. Solamente le recuerda -dedicándole muy poco espacio a este tema- que él debe saber que es un mandatario del pueblo y que, si incurre en tiranía, su pueblo puede oponerle resistencia. Sucedió que el Rey de Francia, Enrique IV, fue asesinado por un demente en las calles de París en 1610. Una cierta opinión pública entendió que esto había sucedido por la propagación de la licitud del tiranicidio que habían realizado los libros españoles. El libro de Mariana, que estaba entonces en boga, fue condenado a la quema pública por el Parlamento de París. El asesino fue interrogado con los métodos propios de aquella época, pero desconocía estos libros.
} 
hecho al crear por primera vez el Estado en Occidente. A partir de ahora el planteamiento fue distinto, porque ya no se trató de luchar contra el poder establecido (un problema ante todo de auctoritas) sino el de combatir para que el poder existente fuera obedecido: una cuestión de imperium. En cierto modo, los atacantes se convirtieron en defensores del orden existente, aunque este hecho no se apreció con claridad hasta finales del siglo XX. La Declaración de Derechos de 1948 fue una primera advertencia, pero quedó ahogada en el territorio tan extenso de los países comunistas.

En un primer momento, ya muy estabilizada la constitución del Estado, los positivistas mostraron varias actitudes que confluían en la misma meta. De un lado, afirmaban beligerantemente que ellos exponían el derecho verdaderamente racional, no ensueños que sólo habitaban en libros escritos por personas privadas. $\mathrm{O}$, dicho de otra forma: los positivistas reivindicaban el derecho nacional dictado por el representante del poder de la Nación porque ellos querían hacer realidad el Estado como la nueva forma de convivencia y de dominación.

A pesar de su deuda con los jusnaturalistas anteriores, los positivistas del siglo XIX se mostraron como tales ante todo por su antipatía hacia los tratados del derecho natural y frente los sistemas de ética que cierran el Iluminismo. Pero afirmar el deber de cumplir el derecho legalmente existente implicaba cegar las otras posibilidades de la racionalidad práctica. Por esto en un primer momento lucharon contra la idea de una moral objetiva e inmutable ${ }^{103}$ y más adelante, contra la idea del derecho natural. En esta última empresa destacó especialmente Carl Bergbohm denunciando algo compulsivamente lo que él llamaba el «Dualismus in der Rechtslehre» porque, afirmaba él, donde está vigente un derecho no puede estar vigente otro derecho ${ }^{104}$. (Era evidente que Bergbohm no trascendía la imaginación geométrica). Kelsen, igualmente, vio el enemigo a combatir ante todo en el derecho natural.

Aunque distingamos varias generaciones de positivistas, todos ellos coinciden en la negación de esas nociones metafísicas que son la cualidad personal del ser humano y la existencia de los derechos y deberes estrictamente jurídi-

${ }^{103}$ Vid. la parte histórica de CARPINTERO, F., Una introducción a la ciencia jurídica, Civitas, Madrid, 1988. Frederick Harrison siguió un camino intermedio y estableció que el Estado es omnipotente para los juristas, pero no para los filósofos o los moralistas. HARRISON, F., On furisprudence and the Conflicts..., op. cit., p. 30.

104 Bergbohm, C., furisprudenz und Rechtsphilosophie..., op. cit., pp. 109 y ss., en donde trata «Der Dualismus in der Rechtslehre». 
cos: sólo admitían un mundo de normas que habían de ser conocidas cognitivamente. No son tan honestos -ni tan ingenuos- como para negar expresamente que todo ser humano es una persona; pero dejan en sordina la cualidad personal y la realidad del deber. Realmente, ¿ellos, en sus vidas cotidianas, no creen en las personas, ni en el deber, ni en la moral? Porque en su discurso cotidiano y bien real son especialmente proclives a hablar de la moral. Aquí no cabe una media via, como sería la de remontarse a una teoría que volviera normativo al derecho pero negando el 'deber' de obedecerlo: puede haber motivos para obedecer o desobedecer a una norma concreta, pero no una meta-teoría del derecho que lo valide deónticamente al margen de la prosaica y corriente realidad del deber. Negaron cualquier fundamento meta-positivo de los contenidos del derecho y afirmaron su simple existencia. Parecían seguir el adagio que dice «Funciona, luego es válido».

Llevan dos vidas y la negación de estas realidades -el deber y la personalidad- no traspasa las páginas de sus libros o sus explicaciones de clase. Con razón habla Ollero, para referirse a ellos, de «filosofías de doble lenguaje» ${ }^{105}$, y Massini de «esquizofrenia» ${ }^{106}$, tesis en la que abunda este último autor cuando indica que «Corresponde destacar que en todas las doctrinas mencionadas se da algo

105 Andrés Ollero llama a esta actitud «Cultura de doble lenguaje». OlLERO, A., Derechos humanos. Entre la moral y el derecho, UNAM, México DF, 2007, p. 240. Añade que «Ser positivista y riguroso a la vez, resulta fácil cuando se está dispuesto a suscribir que las exigencias éticas (tanto las propiamente morales como las jurídicas) no son susceptibles de fundamentación racional alguna; algo tan reñido con la realidad cotidiana del derecho, como para asumir que los jueces no pueden emitir 'juicio' alguno». Ibid., p. 318. Se remite a R. L. Vigo, que escribe que «Nos parece bastante evidente que el iuspositivismo se mueve más cómodo en el mundo académico que no entre los operadores jurídicos y la concreta realidad jurídica». VIGO, R., El jusnaturalismo actual. De M. Villey a 7. Finnis, Fontaneda, México, 2003, p. 200.

Carlos Massini hace notar esta paradoja de los relativistas que, sin embargo, sí afirman los derechos humanos. Es la actitud paradójica de los que mantienen que los derechos son indemostrables, etc., pero dan por supuesto, sin embargo, que son deseables. Vid. MASSINI-CorREAS, C.I., Los derechos humanos en el pensamiento actual, Abeledo-Perrot, Buenos Aires, 1994, p. 137. Ya ha explicado en la página 104 que habría que entender, de acuerdo con estos relativistas, que sólo podríamos defender a los derechos casualmente.

106 Massini escribe que «La afirmación simultanea: $i$ ) de la cognoscibilidad veritativa de las exigencias de la justicia, y $i$ ) de la total independencia del derecho respecto de esas exigencias, conduce inevitablemente a una especie de esquizofrenia intelectual, según la cual existiría un deber estricto de obedecer un mandato que se reconoce objetivamente - con pretensiones de verdad- como grave y evidentemente inicuo. La realidad es que existe en el intelecto humano una exigencia intrínseca de unidad, un requerimiento de coherencia que transforma en irrealizable la pretensión de sostener dos afirmaciones que implican de un modo estricto una insalvable contradicción». Massini Correas, C. I., Constructivismo ético..., op. cit., p. 67. 
por supuesto más allá del consenso, es decir, se aceptan como verdaderas ciertas premisas no sujetas a la prueba del consenso. Así, p. e., Bobbio supone gratuitamente y sin intentar siquiera demostrarlo, que los Derechos Humanos son algo «deseable»y, por lo tanto, bueno. Perelmann da por supuesto el valor de las reglas de la retórica, que son previas al asentimiento del «auditorio universal», y Habermas presupone el valor de las leyes del «discurso libre de dominio», leyes que no están sujetas a la prueba del consenso. Esto significa que estos autores... terminan aceptando al menos una afirmación que no es relativa y que funciona como supuesto de todas las demás» ${ }^{107}$. Una realidad cuya descripción que acaba de exponer Spaemann cuando indica que lo único que dicen es que esos modos de actuar son funcionales o disfuncionales con referencia a un estado por sí indiferente, el cual, por causas de nuevo indiferentes, les aparece como digno de ser deseado a aquellos que expresan el entusiasmo o la condena ${ }^{108}$.

\section{Deber y cotidianidad}

El derecho no es pensable sin coacción organizada ni sin la noción del deber. La coacción no suple al deber pues, como indicaba Rousseau, si es necesario obedecer por fuerza, no es necesario obedecer por deber. Ninguno de estos dos términos, siendo ambos necesarios y ocasionalmente opuestos, suple al otro. No siempre coinciden porque, aparte de que aparece a veces la prepotencia, los gustos están dispuestos de formas diversas: por este último problema crearon los escolares de la Baja Edad Media la figura de las «leges mere poenales» ${ }^{109}$.

Hay que hablar de la razón práctica que crea el deber de obedecer al derecho porque las reglas o las normas jurídicas responden a necesidades humanas, y si una norma no hace frente a una necesidad, la razón manda que se la considere abuso de poder. En un primer momento, vemos que hay exigencias morales elementales que, por imperativos ineludibles de la condición humana,

${ }^{107}$ Ibid., pp. 137-138.

108 SpaEMANN, R., Lo natural y lo racional. Ensayos de antropología, trad. D. Innerarity y J. Olmo, Rialp, Madrid, 1989, p. 69.

109 No a todos les convencían algunas leyes. Desde la Alta Edad Media, algunos teólogos que afirmaban el deber en conciencia de obedecer a las leyes, mantuvieron que, en los casos de los disconformes, no pecaban si no cumplían esas leyes de las que discrepaban. Así salvaban la autonomía personal. Pero estos disconformes quedaban obligados en conciencia a pagar la multa establecida: de este modo salvaban el principio de autoridad. 
han de alcanzar el plano jurídico. Georges Ripert estudió este tema en su breve ensayo «La regla moral en las obligaciones civiles». Indicó que las estudiaba en el derecho civil y mercantil porque hubiera sido demasiado fácil destacarlas en el derecho de familia. (Savigny entendía que el derecho de familia era puro derecho natural ${ }^{110}$ ). Efectivamente, si en todos los ordenamientos jurídicos ha de haber una regla que indique que «Todo el que cause daño a otro mediando culpa o negligencia está obligado a reparar el daño causado», esta regla existe y ha de existir porque la exige el fundamento mismo de la moral, es decir, de la vida propiamente humana. (Aunque el aumento del normativismo en nuestras vidas hace dudar de esta afirmación).

También interviene la historia en un desarrollo notablemente más pragmático. La razón práctica que desarrolla la moral atiende no sólo a principios ya constituidos, sino que la misma razón política es o debe ser de valor moral por sí misma. Un viejo dicho medieval establecía que «Philosophus est in mundo sicut filius in domo», y podríamos decir -cuestión de parafrasear todo lo que sea posible- que Cives est in societate sicut filius in domo, es decir, el derecho ha de hacer frente a las necesidades que van surgiendo progresivamente. Montesquieu dedicó su obra más conocida a mostrar cómo los Romanos dictaron las leyes que eran necesarias en cada momento, y fue lógico que estableciera que las leyes son las relaciones necesarias que surgen desde las naturalezas de las cosas. El acertar políticamente con lo más oportuno no es simplemente una exigencia política: es una exigencia ante todo moral.

Aparte de los principios y de las subvenciones de las necesidades existe otra dimensión de la filosofía práctica que se nos muestra preferentemente en el interior de los desarrollos argumentativos de la ciencia jurídica. Ya aludí a que la moral en el derecho se desarrolla en dos planos, y ahora puede ser el momento de ejemplificar esta segunda vertiente del derecho. Acompañé a un abogado a la ciudad de Huelva. El problema era que un cliente suyo, fabricante de vigas para la construcción, había vendido una partida de viguetas a una

110 Él entiende que el Derecho de Familia es derecho natural. SAvigny, F. C. von, System der heutigen römischen Rechts, Berlin, 1840, Band I, $\$ 56$, p. 370. En cambio, mantiene que el «Obligationenrecht», etc., no posee un contenido directamente moral o no pertenecen al derecho natural porque existen «ohne Rücksicht auf die sittliche oder unsittliche Ausübung eines Rechts». El Vermögenrecht no tiene un contenido moral propio. Loc. cit., p. 371. Separar de este modo al derecho de la moral parece demasiado fuerte, incluso tratándose de una persona con el prestigio de Savigny. Para Ripert, vid. RIPERT, G., La regla moral en las obligaciones civiles, trad. Carlos Valencia Estrada, Ediciones Olejnik, Valparaíso/Grupo Editorial Ibáñez, Bogotá, 2017. 
empresa constructora que estaba levantando un edificio de bastantes pisos en la ciudad indicada. Las vigas les fueron entregadas a los de la empresa y ellos decidieron colocarlas en lo alto de la construcción, en el radio de acción de la grúa, y sin ninguna sujeción. Sucedió lo previsible: la grúa tropezó con las viguetas, éstas cayeron al suelo y mataron a un trabajador en su caída. Los abogados de la empresa constructora demandaron al fabricante de la grúa, al de las viguetas y a otras empresas. El juez nos recibió amablemente, se firmaron los documentos en los que la empresa fabricante de las vigas declinaba toda responsabilidad en lo sucedido, y el caso fue archivado. No cabía otra solución justa. Esto, ¿se basaba en el conocimiento del derecho, en el sentido para la justicia, en la prudencia? No sería posible determinar una sola fuente. Pero es un hecho a remarcar que los que hablan del derecho natural, de la justicia objetiva, etc., se remontan solamente al plano de los grandes principios, como si las exigencias de la justicia se consumieran en ellos. Por el contrario, quieren desconocen (verbalmente) estos razonamientos que es necesario hacer moralmente y que poseen y debe poseer influencia inmediata en el derecho. En el plano de los estudios y discusiones sobre los grandes derechos y en las teorías globales sobre la justicia, el desacuerdo está anticipado de antemano. Pero no exageremos los desacuerdos: estamos todos concordes en que no podemos poner demasiado alto el aire acondicionado de la Facultad y en que el fabricante de las viguetas antes aludido era inocente en lo que se había producido.

¿Qué piensan sobre estos temas los defensores de los solos derechos? Aparte de incoherencias 'serias' 111 , los bravos defensores de los derechos han olvidado una advertencia muy elemental que opera en todas las ramas de las ciencias, a saber, que «las conexiones metódicas vienen inspiradas por una metafísica implícita o explícita, cuyas conexiones efectivas con la ciencia quedan siempre por demostrar $\gg^{112}$. Se trata de ideas o sentimientos muy personales, que más residen en la parte irascible del hombre que no en la cogitativa y, por esto, René Dubos nos decía apasionadamente que «No hay, no, nada, que pueda llamarse método de descubrimiento» ${ }^{113}$. Ya aludí a esa 'metafísica', normalmente implícita por no mostrada, que hacen que el objeto conocido y los sujetos observadores formen un único cuerpo.

\footnotetext{
111 Gerhard Frey indicaba que «Cuando alguna de sus propiedades incurre en contradicción, entonces la teoría, en su totalidad, aparece como falsa, ya que ella constituye una unidad lógica libre de contradicción». FreY, G., La matematización..., op. cit., p. 106.

112 Saumells, R., La ciencia y el ideal metódico, Rialp, Madrid, 1958, p. 142.

113 Dubos, R., Los sueños de la razón, trad. J. Almela, UNAM, México, 1996, p. 130.
} 


\section{Derechos, coacción, cosas}

Obviamente el derecho no puede ocuparse de todas las necesidades de los hombres: esto sería imposible y, además, indeseable. Desde luego, no existe un límite rígido que determine de lo que ha de ocuparse el derecho: diversos autores alemanes de comienzos del siglo XIX publicaron monografías sobre los límites del poder del Estado; pero estos autores eran normalmente liberales y ya antes de comenzar a redactar sus obras tenían claros esos límites. No eran estudios de investigación sino de defensa de algunos de algunas de las teorías sobre los derechos entonces exigidos. Más tarde el derecho ha pretendido ocuparse de casi todo, y éste ha sido al caso de algunos totalitarismos que florecieron en el siglo XX. En cambio, otros autores que han publicado sobre este tema quieren Estados 'de mínimos', y tal ha sido la actitud del Partido Republicano de los EEUU y de algunos autores actuales como Nozick o Buchanan. Entremedio ha surgido el Estado Social de Derecho, y éste sería el caso de Estados como Italia, Francia o España.

Las consideraciones expuestas antes sobre la ciencia del derecho son poco inteligibles, o poco valoradas para quienes confunden la jurisprudencia con los derechos humanos. Sabiendo que no podemos tomar la parte por el todo, es preciso aludir positivamente a estos derechos. Hay quienes piensan que ellos constituyen hoy las concreciones propias del derecho o ley natural. Esta cuestión, así planteada, es vidriosa porque tanto expresa una verdad como muestra insuficiencias. Si fuera cierto sin más que los derechos expresan hoy la ley natural, poco habría que añadir. Justamente éste es el problema, ver como lo grandioso de los derechos ha de encarnarse en las concreciones propias de la cotidianidad, esto es, en la única vida real. Al filo de esta vivencia, habría que hacer dos observaciones.

Una, que los derechos son realidades más complejas que los poderes de los individuos, es decir, son algo más que derechos subjetivos ${ }^{114}$. Se ha convertido en un tópico que todos reconocen al decir que el lenguaje actual sólo habla de derechos y no de deberes, y este tópico tiene razón de ser porque, si consideramos nuestras vidas sólo bajo el visor de los derechos, nuestra cotidianidad únicamente mostraría las pugnas entre individuos enfrentados permanentemente. Viendo en el día a día cómo funciona fluidamente la vida social

\footnotetext{
114 Vid. CARPINTERO, F., «Persona y officium: derechos y competencias», en Rivista Internazionale di Filosofia del Diritto, LXXIII (1996), pp. 3-59.
} 
en nuestras sociedades extremadamente complejas, hay que concluir que la cooperación social acompaña necesariamente, tamizándolos, a los derechos. Ante esta realidad la mirada tiende a volverse a algunos autores franceses que se llamaron a sí mismos 'solidaristas', como fue el caso -cada cual a su modode Duprat o Hauriou. Pero, aunque sus obras muestren un ejemplo valioso de una reacción contra el posible subjetivismo de los derechos, no sirven porque recuerdan demasiado a sociologismos en los que las personas quedan arrinconadas contra algunas de sus funciones sociales.

La segunda observación consiste en reconocer que entre los derechos y el derecho como actividad diaria y prosaica existe una relación similar a la que se da entre las leyes y los reglamentos. No sirve una ley sin reglamentos que la desarrollen; además, los reglamentos pueden desplegar a las leyes de formas distintas.

La impresión que finalmente obtiene el estudioso es que, supuesto el respeto a los derechos colectivos e individuales, una sociedad valdrá lo que valga la calidad de la cooperación con la que funciona. Si la capacidad de cooperar es de mala calidad, se hará realidad lo que indicaba una ministra de Sanidad italiana, hace unos quince años: «Tenemos la legislación más perfecta del mundo y aquí no funciona nada». Una Administración que tanto consume dinero como esfuerzos de las personas para, a cambio, dar poco, es una realidad inmoral, es decir, contra la justicia. Se hace realidad el adagio que expresa que «Lex iniqua est quae plus mali, quam boni affert ${ }^{115}$.

Hay que reparar en que buena parte de nuestros principios políticos responden a la moral más dominante en cada momento, que, desde las Lectures de John Austin, se viene llamando moral positiva. Esta moral tiene bandazos, y quien se identifique con el estado de cosas actual -por ejemplo, viendo en sus libertades un hecho histórico irreversible- debe saber que él es un partícipe más de esta moral impersonal y que lo que él o ella considera derechos, deberes o libertades básicas de él, de los otros o de la Administración, son vivencias que en buena medida están sometidas al cambio histórico, y que es bastante probable que piense de forma distinta dentro de treinta años. Pero esta comprobación no lleva al nihilismo en los valores que aprecian la importancia de los bienes humanos y, dentro de lo posible, hay que destacar algunas exigencias incuestionables.

Platón y Aristóteles hablaron de las 'cosas', aunque tratándolas de formas algo diferentes porque Aristóteles no afirmaba las Ideas pero sí los conceptos,

115 Major, J., De libertate christiana liber, Lovanii, 1540, p. 79. 
aunque distinguiera los contenidos mentales que forma cada persona al percibir algo y los conceptos universales en los que reposaban esos conceptos. Son 'cosas jurídicas', es decir, conceptos relevantes jurídicamente, el hecho de vivir en un inmueble, conducir un automóvil o ejercer una profesión. En un grado más intenso son igualmente cosas las condiciones de ser esposa, o marido, ser padre o ejercer una profesión ${ }^{116}$.

Está mal visto hablar de las cosas porque desde Hobbes a hoy el nominalismo que niega la existencia de las cosas se ha impuesto por lo general. Aunque si leemos detenidamente a Hobbes, y más tarde, a Locke o Hume, ellos atacaban lo que llamaban las 'sustancias' ${ }^{117}$. Entendían que las sustancias eran cuerpos que existen en sí y por sí (en el espacio), y afirmaban que esto era absurdo. Porque los indios -escribía Locke- mantienen que la Tierra está sostenida sobre los hombros de un gigante, y que el gigante se apoya sobre un elefante y éste en una tortuga; pero ¿en qué se apoya la tortuga? ${ }^{118}$.

Dejemos de lado estas polémicas algo pintorescas. Sucedía que entre Locke y Hume se interpuso Newton, y la explicación mecánica de Newton incluía todo lo existente en la Máquina Universal, que era la única realidad. Hablar de sustancias distintas absolutamente unas de otras, cada una existiendo para sí misma, era un absurdo, porque únicamente puede existir para ellos

116 Este es un brocardo medieval de uso corriente. Aún lo emplea John Austin, en siglo XIX, cuando escribe que «But, instead of denoting 'men' (or human 'being'), it sometimes denotes the condition or status with wich men are invested. And taking the term in this signification, every human being who has rights and duties bears a number of persons. 'Unus homo sustinere plures personas...». Austin, J., Lectures on Furisprudence..., op. cit., vol. I, p. 532. Las intensidades son de Austin. Cito a Austin porque él dedica mucha atención a esta noción de 'persona'. Lo mismo sucedía con Markby y Holland.

Sin embargo, no podemos exagerar la operatividad de esta noción. John Austin, dentro del espíritu de esta jurisprudentia, escribía «For all the perplexing questions which the science of jurisprudence presents, the notion of 'status' or 'condition' is incomparably the most difficult». AusTin, J., Lectures on Furisprudence..., op. cit., p. 351.

${ }^{117}$ Hoy estamos en una situación parecida, aunque sin el primitivismo del siglo XVIII. Habermas nos indica que «Existen indicios suficientes que abonan la hipótesis de que categorías tales como espacio, tiempo, causalidad y sustancia y las reglas que rigen el enlace de símbolos en la lógica formal tienen un fundamento prelingüístico y que el lenguaje se limita a «asentarse» sobre ellas. Habermas, J., La pretensión de universalidad de la bermenéutica, en ID., «La lógica de las ciencias...», op. cit., p. 284.

118 LOCKE, J., «Essay of Human...», op. cit., vol. I, p. 16. No se trata de descalificar a Locke sin más, porque Saumells, por ejemplo, reconoce que el espacio absoluto y el tiempo absoluto de la mecánica son el espacio y el tiempo de la imaginación estricta. SAUMELLS, R., La ciencia y el ideal..., op. cit., pp. 160-161. Pero la inmadurez de Locke, que le lleva a entender a cada sustancia como un paquete de 'materia' situado en un lugar inestable, no es admisible. 
un protoelemento que va presentando caras distintas y que es tan único como lo es el movimiento de la máquina tan total como única en que consiste, en definitiva, toda manifestación de la vida. Newton, viendo el uso que algunos materialistas hacían de sus explicaciones, publicó, a modo de apéndice de la segunda edición de sus «Principios», un tratado de teología natural en el que llamaba al espacio infinito «el sensorio de Dios» ${ }^{119}$. Pero fue tiempo perdido porque desde la extensión de su obra se desarrolló una mentalidad científica que excluía a Dios del mundo («Deus ex machina») y que, por el mismo motivo, excluía al hombre de la máquina universal: Homo extra machina. Aunque el desarrollo de la física en el siglo XX ha matizado severamente esta visión del Todo Universal, este 'materialismo' mecanicista ha permanecido inconfesadamente porque algunos entienden que, a pesar de todo, el tiempo volverá a poner las cosas en su sitio y estaremos en condiciones de entender renovadamente este movimiento único que todo lo critica. La obra de Luhmann parece responder a esta última mentalidad.

La actitud escéptica es muy antigua (como comprobamos en la aporía que propone Zenón sobre la carrera entre Aquiles y la tortuga), y en cierto modo la comparte el autor de estas líneas, que confiesa que no sólo no sabe nada acerca de lo que sean el tiempo o el espacio, sino que además está convencido que el psiquismo humano no tiene capacidad para entender estas cuestiones más elementales, que le desbordan. Pero desde esta comprobación -al menos una comprobación de lo que él cree no saber- no deduce que no afirme la cosa de la docencia, y entiende que la docencia, por ser una realidad que existe objetivamente, le obliga realmente a preparar sus clases para que sus alumnos le entiendan. La docencia es un concepto que expresa una 'cosa', y esto no es nada singular porque todas las cosas humanas presentan sus exigencias propias.

${ }^{119}$ Este 'sensorio de Dios' fue identificado pronto con el espacio (¿?) material y las reglas de la moral y de la justicia sólo podían ser funciones de la extensión material. Así, por ejemplo, Condorcet explicaba que «Ainsi, l'analyse de nos sentiments nous fait découvrir, dans le développement de notre faculté d'éprouver du plaisir et de la douleur, l'origine de nos idées morales, le fondement des vérités générales qui, résultant de ces idées, déterminent les lois immuables, nécessaires du juste et de l'injuste; enfin, les motifs d'y conformer notre conduite, puisés dans la nature même de notre sensibilité, dans ce qu'on pourrait appeler, en quelque sorte, notre constitution morale. Cette même méthode devint en quelque sorte un instrument universel; on apprit à l'employer pour perfectionner celle des sciences physiques, pour en éclaircir les principes, pour en apprécier les preuves; on l'étendit à l'examen des faits, aux règles du goût». CONDORCET, J., Esquisse d'un tableau historique des progrès de l'esprit humain, Flammarion, Paris, 1988, p. 223. 
Estamos rodeados de cosas que son puntos de encuentro entre los seres humanos: el profesor y sus alumnos se tratan $-\mathrm{y}$ deben tratarse- de formas muy determinadas que desbordan ampliamente las simples reglas del trato social, porque están vinculados por una realidad; y cualquiera de nosotros trata con los empleados de un supermercado gracias a unas instituciones concretas del derecho mercantil. Pero si tomamos solamente como referente de las relaciones jurídicas el derecho real de propiedad, no observaremos tantos puentes entre las personas, porque las propiedades frecuentemente excluyen. Pero junto a las propiedades, y dependiendo de ellas, están los contratos de compraventa, de alquiler o la constitución de usufructos, que nos facilitan buena parte de nuestra vida. Estos hechos más concretos suelen ser pasados por alto por los filósofos y los sociólogos, que son personas que no viven y reflexionan en el interior del derecho, y con razón se quejaba el juez Holmes, hace ya un siglo que las explicaciones sobre lo que es el derecho comenzaran desde el bad man. El orden jurídico no parte siempre desde los delitos ni desde las exclusiones ${ }^{120}$.

Este carácter más propiamente real de las cosas, es decir, de la vertiente semántica de las palabras, lo observa mejor el jurista que no el filósofo. Un filósofo 'puede' ser nominalista, pero un jurista no. Pues un ciudadano no puede decir ante el juez, como ya quedó indicado, que él no respeta los límites de la velocidad en el tráfico rodado porque él usa unos referentes distintos para entender y enjuiciar el lenguaje y no sabe ni puede saber lo que es un límite o lo que es la velocidad. La objetividad se muestra en su mayor grado en la posibilidad tan cotidiana de entendernos todos y de exigir a todos que entiendan. Aquí, la prosa del jurista destruye los encajes delicados del filósofo analítico; pero es el jurista el que tiene razón porque sin una noción de los que son las cosas no podría ni comenzar su trabajo.

Indicaba antes que si tan difícil es reconocer que el profesor tiene el deber objetivo de preparar sus clases con sentido de la responsabilidad. La do-

${ }^{120}$ Estas visiones que entienden al derecho ante todo como un conjunto de restricciones no han superado su entendimiento como realidad negativa y sancionatoria. Sin duda el derecho trata de prohibir conductas nocivas para todos. Pero con mucha más frecuencia nos 'habilita para': él pone los cimientos para esa obra prodigiosa de todos los días a la que nuestra visión pobre y dada al acostumbramiento no siempre sabe valorar. El que haya Universidades, editoriales, puestos de trabajo en las ocupaciones más diversas... Nada de esto es negativo ni represivo sino todo lo contrario. Toqué este tema en otro momento, y a ello me remito. El hombre multiplica mil veces sus fuerzas gracias a la colaboración social. ¿Alguien piensa en las miles de horas de estudio, diseño y trabajo que ha costado el bolígrafo que usamos cotidianamente? Vid. CARPINTERO, F., «El derecho penal en la definición del derecho», en Persona y Derecho, 40 (1999) pp. 307-322. 
cencia es una cosa, y esto parece indiscutible. Pero desde el siglo XVII a hoy todos los que han negado la existencia del deber de cumplir el derecho han sido fenomenistas que excluían el conocimiento de las cosas reales también en el derecho. Thomas Hobbes fue el autor más paradigmático porque negó la existencia de la cualidad personal del hombre, de la libertad personal, del deber de cumplir el derecho, y estableció la imposibilidad de conocer lo que las cosas son. Desde entonces, cualquiera que se asome a una biblioteca, comprobará que estas exigencias vienen exigidas por los autores que genéricamente llamamos materialistas. Para ellos se suficiente que existe un orden general en cada sociedad, institucionalizado y que sea coactivo.

Por el contrario, MacIntyre nos ha dejado la noción de 'conceptos funcionales', ya que ser capitán de barco o la comida en familia son nociones que comportan su propia racionalidad, que se impone en el derecho. Quien tenga en cuenta que los argumentos que hay que dar a un marido que adultera, a un juez que prevarica o a un conductor que conduce imprudentemente, son argumentos necesariamente distintos, comenzará a entender las vertientes ontológicas de las reglas y normas jurídicas.

\section{LA PERSONA, UNA HERENCIA DIFÍCIL}

En un estudio dedicado a mostrar que existe el saber que llamamos jurisprudencia y que este saber no es arbitrario, hay recabar el tener en cuenta a las cosas, a los derechos y a los deberes, y a la índole personal del hombre. En estos temas, a los juristas suele sucederles lo que le acaecía a aquel personaje de Molière que hablaba en prosa sin saberlo. Muchos juristas hacen jurisprudentia sin ser conscientes de la naturaleza de su trabajo, de los anclajes de sus razonamientos, de los índices que siguen para relacionar la letra aparentemente muerta con los hechos vivos, y uno de estos tópicos es el de la personalidad humana. Pascal nos dejó escrito «Sabed que el hombre supera infinitamente al hombre», y la realidad contenida en esta idea ha sido el Cabo de Hornos de todos los que no pueden aceptar realidades metafísicas.

La noción de persona fue una creación conceptual de algunos Padres de la Iglesia que habían de explicar el misterio de la Trinidad; finalmente acordaron que Dios es uno solo pero que tiene tres personas distintas. Algunas de estas enseñanzas se conservaron a lo largo de la Alta Edad Media, y llegaron al enorme renacimiento cultural del siglo XI ampliamente conocidas y en algunos casos potenciadas. La noción de persona fue uno de estos conceptos que 
llegó con fuerza al inicio del segundo milenio. Para nosotros, estudiosos en el siglo XXI, es un secreto por qué el derecho canónico y el derecho romano adquirieron un cariz tan marcadamente individualista o personalista desde el inicio de la Escolástica. Porque, para aquellos escolares, la persona, que se definía ante todo por su incomunicabilidad, constituía la última soledad del ser (tesis de Scoto) y la escuela scotista mantuvo que cada persona se encontraba por encima de la ley natural y de los derechos humanos, ya que cada una de ellas se apoyaba ante todo en sus derechos, dominios y libertades concedidos por la Prima justitia Dei.

Por parte de los juristas, en sus glosas y comentarios al derecho romano quedó proclamado que el esclavo, que estaba reducido a la nada por el derecho positivo, era, sin embargo, libre según el derecho natural, y como esta última condición no la pierde siempre y en todo caso, el esclavo puede obligarse civilmente dando su palabra: de ahí la doctrina de la 'obligación natural', que mantiene que la única obligación verdaderamente adecuada al derecho natural es la que se origina, para todos los hombres, prestando el propio consentimiento y que en el caso del esclavo surte también un efecto propiamente jurídico ${ }^{121}$. El derecho canónico se encontraba plagado de dominios, libertades y derechos de los clérigos frente a sus superiores, y los historiadores hablan del 'constitucionalismo medieval', cuya última expresión fue el Concilio de Constanza, en la primera mitad del siglo XV. Pero desde el siglo XV en adelante el desarrollo de las ideas jurídicas (con su correspondiente reflejo en la praxis social) fue avance en monarquía pura, hasta llegar al absolutismo monárquico.

Los filósofos que reclamaron con más fuerza la libertad de cada persona fueron Scoto y Ockham, y sus tesis fueron popularizadas por algunos filósofosteólogos del siglo XV, tales como Juan de Gerson, Jacobo Almayn, Pedro Alliacus, Conrado de Summenhart o Gabriel Biel. Ellos, ante muchas dificultades jurídicas, se remiten directamente a la cualidad personal del hombre ${ }^{122}$, como si la qualitas personalis diera de sí lo suficiente como para resolver casi todo. Por el

121 Vid. CORTESE, E., La norma giuridica. Spunti teoretici nel diritto comune classico, Milano, 1963, vol. I. Un estudio más asequible puede ser el de CARPINTERO, F., «El derecho natural laico de la Edad Media», Persona y Derecho, VIII (1981), pp. 33-100.

122 Vid. Carpintero, F., La ley natural. Historia de un concepto..., op. cit., ID., La ley natural. Historia de una realidad..., op. cit. ID., Sobre la ley natural. Una historia controvertida, Ideas y Libros Ediciones, Madrid, 2017. Este último estudio presenta la ventaja sobre los anteriores, de que se expresan en él las preguntas, etc. de un debate -patrocinado por AEDOS, en la Universidad de Comillassobre ID., La ley natural. Historia de un concepto controvertido, Encuentro, Madrid, 2008. 
contrario, la mayor parte de los que integraron la Segunda Escolástica Española apenas alegaron, como título o causa jurídica la personalidad humana.

En este ambiente, hubo una débil vuelta al tomismo en el siglo XVI, pero los escolásticos que cierran la Segunda Escolástica Española -caso de Luis de Molina y Francisco Suárez- se inspiraron más en Scoto y Gerson que no en Tomás de Aquino. Suárez especialmente fue el gran educador de los jusnaturalistas modernos, conservadores o creyentes, del siglo XVII. Se le consideró como un metafísico, por lo que fue especialmente tenido en cuenta por los creyentes. En pocas palabras, el siglo XVII se abre con la consideración de que la epifanía de la vida jurídica está compuesta por los dominia, facultates seu libertates de cada persona.

Podemos admitir, algo arbitrariamente, tres escalones en este desarrollo. Scoto o Gerson se remiten a la «Primera justicia de Dios» (Prima justitia Dei) para fundamentar estas libertades. En un segundo momento, Molina o Suárez rompen la figura de la facultas (que presupone una ley prexistente) y se amparan en la ley natural (Molina) o en una qualitas moralis libertatis humana (Suárez) que viene dictada por la propia naturaleza divina. Finalmente, hacia 1670 Samuel Pufendorf impuso considerar a la naturaleza como 'contradistincta' de Dios, y teorizó mucho sobre la libertad de las personas ${ }^{123}$; pero las personas de Pufendorf son ya unos 'hechos' que no exhiben títulos para establecer obligaciones propiamente deónticas. Con Pufendorf acabó de momento el referente doctrinal de la personalidad humana. Porque los autores jusnaturalistas que no eran conservadores sustituyeron de facto a las personas por los seres individuales con las voluntades libres y llevaron a su plenitud a las teorías contractualistas. Era tal la pasión por el momento intelectual, que los discípulos de Christian Wolff nos llamaran 'esencias racionales', vernünftige Wesen, y lo mismo hicieron los discípulos de Kant.

Su nominalismo y su actitud secularizadora les impedían hablar de las personas $^{124}$.

123 Vid. CARPINTERo, F., La ley natural. Historia de una realidad aun por explicar, UNAM, México, 2013, pp. 225-249.

124 Suárez ya detectaba la presencia de ateos al comienzos del siglo XVII, y escribía que «Unde constat, Politicos qui doctrinam illam suadent principibus saecularibus, si sentiant id eis licere, et iure posse talia praecepta, quae sunt contraria religione verae... haereticis esse, vel certe atheos, quod verosimilius est». Op. cit., Tractatus.., L. III, cap. 12, \$5. El adverbio verosimilius es bastante expresivo. Jules Delvaille explicaba que «Le guerres de religion avaient aussi laissé comme conséquence una certaine tendence à l'athéisme: et il avait de nombreux athées à l'époque immédiatement à Descartes». Delvaille, J., Essay sur l'bistoire de l'idée de progrés jusqu'à la fin du XVIII siècle, Alcan, Paris, 1910, p. 177. 
¿Por qué, entonces, la afirmación de las voluntades? La respuesta a esta pregunta puede parecer pedestre pero es la que se impone al lector: una vez eliminadas las referencias a las personas, sólo 'quedaban' voluntades en el status naturae y en la sociedad posterior construida contractualmente ${ }^{125}$. La verdad básica en este punto, que expresa Spaemann, que si el discurso, si todo el discurso hace violencia a las cosas, dado que no hay una naturaleza en la que él se descubra, entonces también todo participante hace violencia a los demás ${ }^{126}$.

Si nos vamos al campo de los materialistas, desde Hobbes en adelante los filósofos de esta corriente negaron la personalidad humana; incluso para Locke, la persona es un 'término forense' que sólo indica quien debe ser considerado responsable por una acción ${ }^{127}$. La doctrina de la imputatio de Christian Thomasius acabó de consolidar, en un plano más práctico, esta negación de las personalidades ${ }^{128}$. De ahí los esfuerzos de Christian Wolff, en el primer tercio del siglo XVIII, por establecer la noción de persona usual, basada en la individualidad incomunicable, en la autoconciencia y en la memoria que permite reiterar nuestra propia individualidad a lo largo de la vida.

¿Qué hemos heredado hoy? Ya indiqué que estamos ante las secuelas, ante todo, de un problema religioso, tal como nos informó Jhering. Del mismo modo que en los tiempos de Platón, el que no es creyente ha de ser 'materialista' de una forma u otra. Pocos cambios ha habido en este punto. Aunque unos y otros han dejado hoy este tema en la cuneta de la historia y se han lanzado hacia la afirmación de los derechos humanos y, como la afirmación de estos derechos no acaba de convencer en un plano antropológico, algunos han

125 Esta actitud parece una constante humana: el politólogo de obra más extendida hoy, John Rawls, niega algún valor que le pudiera llegar a los hombres por su cualidad personal pero afirma la capacidad de decidir a las voluntades. Esto recuerda a un problema que denunciaba Antonio RosminiSerbati hacia 1820. Él explicaba que sus amigos progresistas le indicaban que era necesario un ordenamiento jurídico cierto, único y universal. Cuando él añadía que, además de esto, el ordenamiento debía ser justo, le contestaban sonriendo ante su ingenuidad: «¿Tú crees que nosotros queremos leyes injustas?». Rosmini-Serbati, A., Filosofia del diritto, Milano, 1841, vol. I, p. 3.

126 SPAEMANN, R., Lo natural..., op. cit., p. 142.

${ }^{127}$ Locke entendía que podemos sufrir penas o castigos: gracias a la identidad personal. LOCKE, J., «Essay of Human...», op. cit., vol. II, p. 63. Persona: Is the name for this self. Es un forensic term para afirmar que unas acciones son apropiadas a una per. Seres inteligentes capable of a law. Ibid., vol. II, p. 69. Es un forensic term para afirmar que unas acciones son apropiadas a una persona, es decir, a seres inteligentes capable of a law. Ibid., vol. II, p. 69.

128 Vid. CARPINTERO, F., «Imputatio», Rivista Internazionale di Filosofia del Diritto, LXXXI (2004) 67-108. 
propuesto teorías sobre la justicia. Esquematizando, estas teorías son de dos tipos: las alemanas basadas en los diálogos ideales, y las anglosajonas, que recalcan más el empirismo y se basan en los intereses de sujetos razonablemente egoístas que se encuentran en pie de igualdad.

(Las teorías trataron de complementar a las declaraciones de derechos porque estas declaraciones presentan dos insuficiencias. Una, que, como los derechos han sido establecidos al margen de cualquier metafísica, sin embargo, ellos han de poseer algún fundamento antropológico normativo; ya indiqué que, sin este fundamento antropológico o teológico, las personas sólo pueden remitirse a documentos escritos que no pasan de ser papeles redactados con buena voluntad. No en vano Max Horkheimer indicaba que «Yo opino que los conceptos bueno y malo, por ejemplo, el concepto de honradez y toda una serie de ideas que de momento aún tienen su valor, no se pueden separar por completo de la teología»).

\section{CONCLUSIÓN: COACCIÓN, DERECHO Y PERSONA}

Los escolásticos del siglo XIX, que compusieron un grupo filosófico de franca poca calidad, influidos por las ideas modernas, expusieron en sus tratados en primer lugar el estudio de los derechos de los hombres aislados, $\mathrm{y}$ en un segundo término los derechos del hombre viviendo en sociedad, y sólo entonces hablaban de la familia, de la Iglesia, etc. Este planteamiento no es aceptable porque, quizá exagerando algo, se podría decir que implica una subversión del orden genético real de la persona humana. Olvidan una vieja verdad matemática y geométrica: que la idea de clase es siempre anterior a la noción de individuo.

Dejando a un lado a Scoto y a Gerson, y más tarde contradiciendo a Molina y Suárez, es mejor volver a la explicación tomista, de hecho, poco conocida. Tomás de Aquino define al 'yo' o la conciencia moral como Cum alio scientia. Equiparó el yo a la conciencia porque los Latinos no distinguían entre conciencia y consciencia. Cuando él indica que el hombre, además de ser un ser político es también un ser social, no está pensando en un ser que primero existe y que, 'más tarde' (¿?), hará vida social ${ }^{129}$. Tampoco piensa en 129 Vid. CARPINTERo, F., «Persona, derecho, judicatura», en F. CARPINTERO y M. C. LONDOÑo
(coords.), El derecho a la justicia imparcial, Comares, Granada, 2012, pp. 1-40. 
un ser que posea sus propios conocimientos y que posteriormente se unirá a los demás ${ }^{130}$.

Es demasiado singular tratar a los sujetos aislados, ya que nunca hemos conocido a nadie viviendo de ese modo. Ciertamente, un hombre puede retirarse de la sociedad, pero ése lleva a la polis consigo: de ahí el dicho anglosajón que indica que es fácil sacar a un hombre de la polis, pero es imposible extraer la polis del hombre. Un autor poco conocido, pero lúcido, que publicó a finales del siglo XVIII, Carl Rössig, se extrañaba, ante tanto estado de naturaleza expuesto en los libros del nuevo derecho natural, de esos hombres que sin conocer la sociedad poseen, sin embargo, apetitos profundamente sociales ${ }^{131}$. Y la vida social es extremadamente complicada y, además, compleja: razonar al modo de Hobbes y entender que un pacto social bien concluido nos librará de la complejidad de las relaciones sociales es una ilusión que reposa sobre un simplismo ${ }^{132}$.

El hombre no es un ser sociable porque 'tenga que', 'haya de' o 'le convenga' vivir vida social. Más bien es sociable porque todos hemos sido formados por y en la sociedad. Esto no implica suscribir íntegramente aquellas teorías behavioristas o conductistas a las que tan aficionados fueron los norteamericanos de los años ' 40 y '50 del siglo pasado, que mantenían la construcción social de la realidad. Que el hombre sea social es una realidad que se dilata mucho más alto y profundamente que lo que expusieron aquellos observadores sociales. Sin duda alguna, todos estamos influidos, y a veces decisivamente, por las pautas

${ }^{130}$ Ignoro por qué razones la filosofía aristotélica, la filosofía práctica tomista y la actitud jurisprudencial van estrechamente unidas: pero lo cierto es que quien pretenda entender al de Aquino ha de estudiar las obras de los juristas del fus Commune. Al menos éste ha sido mi proceso al mismo tiempo vital e intelectual. Entre los juristas, el hombre no es un ser que viva en sí mismo o para sí mismo: usando una expresión de A. Bolognettus, la persona era para ellos un ser ya siempre social: Persona est homo in societate implicatus. Dejo ahora de lado la noción de persona como 'persona jurídica', es decir, como el ser que vive inmerso en las conditiones personarum, porque trato de extender la socialidad de la persona más allá de las exigencias de las conditiones en las que todos vivimos en el día a día.

131 Rössig, C., De cautione in tractando jure naturae nostra in primis aetate maxime necessaria, Lipsiae, 1758.

${ }^{132}$ La complejidad es una realidad humana distinta de la simple complicación. Es interesante releer los escritos de Aristóteles para entender este tema. Él tiene ante la vista las relaciones de amistad, de vecindad, profesionales, de ciudadanía y otras más. No trata de partir desde un único rasgo humano, sea éste el miedo, la simpatía, la benevolencia o la realización de los propios intereses, porque cada tipo de relación introduce su propia legalidad. Su visión de la polis es como la una naranja que tuviera dentro de sí gajos de naturalezas distintas. Fue comprensible que su gran discípulo, Tomás de Aquino, describiera al hombre como un ser político y ‘social'. 
que nos impone en cada momento la sociedad: las modas intelectuales son más duras que las otras modas. Desde este punto de vista se puede hablar del hombre simplemente social, pero pretendo ahora hablar del ser alteritari $0^{133}$.

El Cum alio scientia apunta a la génesis y desarrollo de la conciencia y consciencia humanas. Pero si este discurso se prolonga por el plano de los psicólogos, se introducirá por explicaciones muy generales-intelectuales y acabará en divagaciones. A fin de evitarlas, vayamos a filosofía práctica. Es cosa notable reparar en que incluso los que niegan la existencia de una moral objetiva, sitúan la línea divisoria para la responsabilidad propiamente penal en la capacidad para distinguir el bien del mal. (Aparece otra vez el doble lenguaje). $\mathrm{Al}$ delincuente, cuando es juzgado, no se le pide que sea consciente de haber un daño a otro: existen diversas formas, socialmente establecidas, para hacernos daño. Se le exige que sea consciente de haber roto una universalidad que él porta o debe portar en sí.

Lo más sensato es lo que expone Spaemann: «La crítica de Husserl y Frege al psicologismo en la Lógica debería ser hoy una lectura obligatoria para todos los que se ocupan de las teorías generales del conocimiento. Por cierto, que ni uno ni otro pudieron superar el dualismo. Más bien lo agudizaron. No se dieron cuenta del hecho evidente de que tenían que haber surgido un ser pensante antes de que pudieran pensarse pensamientos verdaderos ${ }^{134}$. Que el hombre supera al hombre es más que un aperçu aislado.

Las representaciones de aquellos individuos aislados han introducido a la conciencia colectiva por el camino de la afirmación de las infinitudes individuales. En el seno de esta mentalidad es lógico que cada persona aparezca como un ser plagado de derechos que defienden la libertad de su 'ego'. Es lógico también que, más tarde, haya que proclamar derechos que nos defienden de los demás o de las mayorías de modo que, finalmente, un infinito se opone otro infinito. Tratan de remediar estas contradicciones estableciendo un conjunto formado por reglas lógicas, en las que nos insertan a los individuos (estos individuos, ¿son al menos seres humanos?), cuya funcionalidad consiste en que, si alguien rompe alguna de las expectativas establecidas, se anulan también para él las posibilidades de alcanzar una posición igual en una sociedad bien ordenada.

El sujeto tiende hacia la infinitud y lleva cierta razón Luhmann cuando establece que no se puede afirmar que cada ser humano es un sistema porque

\footnotetext{
133 Carpintero, F., Historia del derecho natural, Punto Rojo, Sevilla, 2020, pp. 94-118.

134 Spaemann, R., Lo natural..., op. cit., p. 45.
} 
el individuo tiende a serlo todo ${ }^{135}$. La vivencia de la infinitud nos acompaña siempre, y Kierkegaard dedicó su obra más conocida -el «Tratado de la desesperación ${ }^{136}$ - a mostrar esa tensión que sólo puede ser resuelta mediante la vuelta a Dios. Una tensión tan grande que, según Hegel, no la podría superar ningún 'ser natural' ${ }^{137}$. Kierkegaard habla de desesperación porque el individuo quiere ser indefinidamente, pero sus posibilidades vitales están siempre tasadas. El individuo se desespera y se contrae en su desesperación. La mentalidad que comenzó oficiosamente en 1789 y que denunció Hegel en la primera parte de su «Filosofía del derecho», a la que llamó «Derecho abstracto», nos ha llevado a este estado. Pero esta mentalidad reproduce una cierta realidad porque existe un 'ego' que trata de escapar de sus compromisos sociales ${ }^{138}$. Pero supongamos que el investigador trata de prescindir de sus condiciones de padre, amigo, profesor o ciudadano en nombre de su infinitud que se resiste a las limitaciones. ¿Qué quedaría de él? Quizá el vago sentimiento de una autoafirmación puramente formal y por eso mismo vacía.

Estas visiones que entienden al derecho ante todo como un conjunto de restricciones, no han superado su entendimiento como realidad negativa y sancionatoria. Sin duda el derecho trata de prohibir conductas nocivas para todos. Pero con mucha más frecuencia nos 'habilita para': él pone los cimientos para esa obra prodigiosa de todos los días a la que nuestra visión pobre y dada al acostumbramiento no siempre sabe valorar. El que haya Universidades, editoriales, puestos de trabajo en las ocupaciones más diversas... Nada de esto es negativo ni represivo. El hombre multiplica sus fuerzas gracias a la colaboración social. ¿Alguien piensa en las muchas horas de estudio, diseño y trabajo que ha costado el bolígrafo que usamos cotidianamente?

135 Luhmann, N., Complejidad y Modernidad: de la unidad a la diferencia, trad. J. Beriain y J.M. García Blanco, Trotta, Madrid, 1998, pp. 59-62.

136 Este título es una abreviatura del título real de esta obra, que es KIERKEGAARD, S., La enfermedad mortal (o de la desesperación y el pecado), trad. D. G. Rivero, Guadarrama, Madrid, 1969.

${ }^{137}$ Hegel, G.W.F., Principios de la Filosofía del derecho o derecho natural y ciencia política, trad. J.L. Vermal, Ed. Sudamericana, Buenos Aires, 1973, \$35, Zusatz.

138 MacIntyre nos advierte que «Esta capacidad del yo para evadirse de cualquier identificación necesaria con un estado de cosas contingente, ha sido equiparado por algunos filósofos modernos con la esencia de la actuación moral. Así, el Agente Moral es que podría salirse de todas las situaciones en las que el yo esté comprometido, y hacer juicios desde un punto de vista universal y abstracto». MACINTYRE, A., Tras la virtud, trad. de Amelia Valcárcel, Crítica, Barcelona, 1987, p. 50. Es lógico que concluya en este mismo lugar de su obra que «El yo especifique moderno, emotivista, no encuentra límites apropiados sobre los que poder establecer juicios: carece de criterios». 
El cum alio constituye a cada personalidad. No se trata de afirmar buenas intenciones, más o menos altruistas, sino de situarnos en la realidad. Reitero: si prescindimos de nuestras 'situaciones' concretas, ¿qué queda de una persona? Como la persona se constituye desde los 'otros', es la conciencia de esta universalidad (la universalidad y la infinitud no se compadecen aunque superficialmente parezcan ir unidas) la que constituye al hombre. Por eso se juzga la actitud interior del procesado en el proceso penal: porque ha roto una universalidad que, por ser de todos, no es suya exclusivamente. Tiene razón Habermas -al menos en parte- cuando indica que la relación de cada ser humano consigo mismo es 'triádica'; en un primer momento el 'ego' sale de sí, reconoce lo más humano, y finalmente regresa a sí convertido en un 'yo' quizá impensable en un inicio ${ }^{139}$.

La limitación del espacio de estas páginas hace conveniente proponer unitariamente varios temas distintos, y esto vuelve algo confusa la exposición. Aunque el investigador se consuela pensando una verdad obvia: que frecuentemente la claridad es el refugio de los que no tienen nada que decir. Además, una cierta confusión de ideas es necesaria, y esta verdad la expresaba Otto Mayer cuando aludía, a comienzos del siglo XX, al «Egoísmo propio de la formación de los conceptos especializados».

$\mathrm{El}$ individuo se atrinchera hoy en los derechos humanos. Si entendemos a tales derechos al modo de posiciones simplemente defensivas, como lo son las trincheras en cualquier guerra, poco hay que objetar; pero en tal caso hay que saber que el momento negativo es provisional. Los derechos defensivos o negativos existen en función de los positivos. Pero hoy es difícil mantener esta actitud porque los liberales de izquierda, ya bien instalados en los medios, condenan toda institución social que permita emprender empresas culturales, religiosas, lúdicas, etc. Isaiah Berlin es muy representativo de esta actitud: él afirma en un comienzo las libertades negativa y positiva y va condenando paulatinamente, con palabras fuertes, las manifestaciones de las libertades positivas. Viene a mantener que, en una sociedad abierta, todo en que entra en un grupo busca en ese grupo el prestigio y el reconocimiento que nunca alcanzará abiertamente en la sociedad; presenta a las asociaciones siendo necesariamente clanes o sectas ${ }^{140}$. No explica que él y los que piensan como él han actuado eficazmente en el con-

139 Habermas, J., La lógica de las ciencias sociales, op. cit., p. 363.

140 Berlin, I., Cuatro ensayos sobre la libertad, trad. B. Urrutia, J. Bayón y N. Rodríguez Salmones, Alianza Editorial, Madrid, 1988, pp. 199 y ss. Algunas aclaraciones sobre el alcance de la 'libertad positiva', en BADIllo O'FARRELl, P., De repúblicas y libertades, Kronos, Sevilla, 2003, cap. 3. 
trol de los medios de comunicación y, normalmente por medio de ingenierías legales montadas laboriosamente, han creado un statu quo que les interesa a ellos mantener en nombre, normalmente, de los derechos propios de los ciudadanos en una sociedad democrática que es cooperativa. Una vez instalado el histrionismo, todos son conscientes del escalón que se ha producido entre las aspiraciones públicas y la realidad social. Entonces entra en acción lo que Hegel llamaba el desgarrón (Zerrissenheit) o el desdoblamiento (Entzweiung) de los ciudadanos, que se vivencian perteneciendo a dos patrias distintas y a veces opuestas, la privada y la pública.

La doctrina política más reciente, siguiendo fielmente un nervio básico de la Modernidad, que es la de la linealidad (ya indiqué que en el jusnaturalismo moderno los individuos pasaban directamente desde la soledad al Estado gracias a estas «Éticas de línea recta») trata de imponer un solo 'espacio público' para discutir nuestros problemas. Vemos, por ejemplo, que tanto el diálogo público de Habermas como la posición original de Rawls sólo reconocen un único momento para la deliberación pública. Desde luego, hay temas que han de ser discutidos públicamente, pero los temas más relevantes para las personas suelen escapar a esta dimensión de lo público ${ }^{141}$. Pero desarrollar esta tesis llevaría demasiado espacio; nos limitamos a dejar el tema así. Sólo podemos ahora hacer constar que la exigencia del espacio único es un ejercicio de hipocresía porque vemos, desde un punto de vista, que quienes se instalan en 'lo público' usan la enseñanza y la sanidad privadas en cuanto adquieren más nivel económico. De otro lado, condenan toda enseñanza moral con pretensiones de ser universal en nombre de 'su' moral, que sí es considerada de hecho verdaderamente universal.

Es lastimoso registrar que quieren una sociedad comunal sin valores comunales, porque la sociedad, en su totalidad, rara vez sirve para otorgar identidad a las personas: con frecuencia resulta ser una meta excesivamente alejada de la cotidianidad propiamente personal. Böckenförde lleva años recordando que carecemos de los valores que dieron origen a nuestra sociedad democrática y al Welfare State.

Pero hoy es embarazoso tocar estos temas porque la tendencia mayoritaria se vuelve compulsivamente hacia los derechos. Pero los derechos no dan

\footnotetext{
141 Vid. Carpintero, F., La crisis del Estado..., op. cit.; ID., Dogmas y escepticismo..., op. cit. Estas mismas ideas en CARPINTERO, F., «La dimensión pública de las personas», en A. APARISI (ed.), Ciudadanía y persona en la era de la globalización, Comares, Granada, 2007, pp. 59-113.
} 
razón de nuestra cotidianidad. Si vuelvo al ejemplo que propuse, el de las vigas para el edificio de Huelva, la solución a este problema encontrará difícilmente remedio si tenemos en cuenta únicamente a los derechos de los trabajadores, de los empresarios, etc. Es cierto que existe y ha de existir la docencia porque es un derecho de los seres humanos. Pero si el profesor tiene el deber de expresarse con la claridad suficiente como para que le entiendan sus alumnos, esta exigencia no se explica ni fundamenta sacando a colación los derechos de los alumnos: más bien está de por medio la 'cosa' de la docencia que discrimina los derechos y deberes más concretos de ambas partes con independencia de lo que convenga momentáneamente a los que toman parte en esta relación.

La verdad sobre este punto la expresaba Cotta: «Es evidente que la compatibilidad de los derechos subjetivos no se deja a la casualidad ni a una adaptación automática del comportamiento: presupone una regla de conducta, una norma». O, por expresar esta misma idea de la mano de John Austin: «But, if the parties... appealed to unmeaning abstractions or to senseless fictions; if they mouthed of «the rights of man», or «the sacred rights of sovereigns», of «inalienable liberties», or «eternal and immutable justice»... A sacred or inalienable right is truly and indeed «invaluable»: for, seeing that it means nothing, there is nothing which can be measured $\gg^{142}$.

\section{LISTA DE REFERENCIAS}

Aquino, T., Quaestiones Disputatae, Edizione Studio Domenicano, Bologna, 1992, q. 22, art. 11, resp.

- Suma teológica, I-II, q. 91, art. 3 ad 2.

ARIMIENSIS, G., lectura super Primum et Secundum Sententiarum, Tomus VI, Super Secundum, 1980, Dist. 34-37, q. 1.

Austin, J., Lectures on furisprudence or the Philosophie of Positive Laww, $5^{\mathrm{a}}$ ed. John Murray, London, 1911.

Badillo O'Farrell, P., De repúblicas y libertades, Kronos, Sevilla, 2003.

BASTIT, M., Naissance de la loi moderne. La pensée de la loi de saint Thomas à Suárez, PUF, 1990.

Bergbohm, C., Furisprudenz und Rechtsphilosophie, Leipzig, 1882.

Bergson, H., «L'évolution créatrice», en Euvres, 5 a ed., PUF, Paris, 1991.

— «Matière et mémoire. Essai sur la relation du corps à l'esprit», en Euvres, $5^{\text {a }}$ ed., PUF, Paris, 1991.

142 Lecture II, p. 119. 
BERLIN, I., Cuatro ensayos sobre la libertad, trad. B. Urrutia, J. Bayón y N. Rodríguez Salmones, Alianza Editorial, Madrid, 1988.

Bertalanffy, L., Teoría general de los sistemas. Fundamentos, desarrollo, aplicaciones, trad. J. Almela, FCE, México, 1989.

BIEL, G., Commentarii doctissimi in IIII Sententiarum libros, Brixiae, 1574, L. II, Dist. 28, q. unica.

BÖCKENFÖRDE, E-W., «Die Bedeutung der Unterschied von Staat und Gesellschaft in demokratischen Sozialistaat der Gegenwart», en Staat und Gesellschaft, Wissenschaftliche Buchgesellschaft Darmstadt, 1976.

- Estudios sobre el Estado de Derecho y la democracia, trad. R. Agapito, Trotta, 2000.

BRYCE, J., «The Methods of Legal Science», en Studies in History and Furisprudence, Clarendon Press, Oxford, 1901, vol. II.

Cabrera, L. Modernidad y Neoescolástica: Anselmo Desing, Universidad de Cádiz, 2001.

CARPINTERO, F. Sobre la ley natural. Una bistoria controvertida, Ideas y Libros Ediciones, Madrid, 2017.

CARPINTERO, F., «¿Regla de reconocimiento o contexto de reconocimiento?», en RAMOs Pascua, J.A. y Rodilla, M. A. (ed.), El positivismo jurídico a examen. Estudios en homenaje a fosé Delgado Pinto, Universidad de Salamanca, 2006, pp. 171-195.

— «Pueden las teorías sobre la justicia sustituir a la doctrina de la ley natural?», en Persona y Derecho 66/67 (2012) pp. 315-352.

— «Crisis de la ciencia, crisis del escepticismo ético», en Dikaion (Univ. de La Sabana, Colombia) pp. 11-52.

— «El derecho natural laico de la Edad Media», en Persona y Derecho VIII (1981) pp. 33 100.

— «El derecho penal en la definición del derecho», en Persona y Derecho 40 (1999) pp. 307-322.

— «Métodos científicos y método del derecho: una historia superada», Persona y Derecho $62(2010 / 1)$ pp. 20-58.

— «Persona y 'officium': derechos y competencias», en Rivista Internazionale di Filosofia del Diritto LXXIII (1996) pp. 3-59.

— «Deber y fuerza: la Modernidad y el tema del deber jurídico», en Obligatoriedad y derecho. XII Fornadas de Filosofía furídica y Social, Universidad de Oviedo, 1991, pp. 151182.

- Del derecho natural medieval al derecho natural moderno: Fernando Vázquez de Menchaca, Universidad de Salamanca, 1977.

— «Derecho y ontología jurídica», Actas, Madrid, 1993.

- Dogmas y escepticismo. Presupuestos de Filosofía del derecho, Escuela Libre de DerechoPorrúa, México, 2013.

— «El desarrollo de la facultad individual en la Escolástica», en CARPINTERo (ed.), El derecho subjetivo en su historia, Universidad de Cádiz, 2003, pp. 35-288.

- El desarrollo de la idea de libertad personal en el pensamiento medieval, Universidad Panamericana-Porrúa, México D.F., 2006.

— «Imputatio», en Rivista Internazionale di Filosofia del Diritto, LXXXI (2004) pp. 25-78. 
- Fusticia y ley natural: Tomás de Aquino, y los otros escolásticos, Servicio de Publicaciones de la Universidad Complutense, Madrid, 2004.

- La Cabeza de fano, Universidad de Cádiz, 1989.

- La crisis del Estado en la Edad Posmoderna, Thomson-Aranzadi, Cizur Menor, 2012.

— «La dimensión pública de las personas», en A. Aparisi (ed.), Ciudadanía y persona en la era de la globalización, Comares, Granada, 2007, pp. 59-113.

- La ley natural. Historia de un concepto controvertido, Encuentro, Madrid, 2008.

- La ley natural. Una realidad aun por explicar, UNAM, México, 2013.

— «La Modernidad jurídica y los católicos», en Anuario de Filosofía del Derecho, V (1988) pp. 383-412.

- «Los constructos racionales en la reflexión sobre la justicia», en Dikaiosyne, 1. ${ }^{\text {a }}$ parte 23 (2009) pp. 25-65, 2. ${ }^{\text {a }}$ parte, 24 (2010) pp. 59-87.

- Los inicios del positivismo jurídico en Centroeuropa, Actas, Madrid, 1993.

— «Persona, derecho, judicatura», en El derecho a la justicia imparcial, F. CARPINTERO-M. C. LONDOÑO (coords.), Comares, Granada, 2012, pp. 1-40.

— «Reducir la complejidad: ¿hacia una razón esotérica», en Estudios en Homenaje al Prof. Andrés Ollero, Congreso de los Diputados, Universidad Rey Juan Carlos, Madrid, 2015, pp. 739-759.

- Una introducción a la ciencia jurídica, Civitas, Madrid, 1988.

Clark, E. C., Practical Furisprudence. A Comment of Austin, Cambridge University Press, 1883.

CocceIUs, S., Tractatus juris gentium de principio juris naturalis unico, vero et adaequato, Francofurti ad Moenum, 1702.

CONDORCET, J., Esquisse d'un tableau historique des progrès de l'esprit humain, Flammarion, Paris, 1988.

CORTESE, E., La norma giuridica. Spunti teoretici nel diritto comune classico, Milano, 1963, vol. I.

Couturat, L., Les principes des Matémathiques. Avec un appendice sur la philosophie des Matémathiques de Kant, Paris, 1905, G. Olms, Hildesheim-New York, 1979.

DANZ, E., Richterrecht, Carl Heymann, Berlin, 1912.

Delvaille, J., Essay sur l'bistoire de l'idée de progrés jusqu'à la fin du XVIII siècle, Alcan, Paris, 1910.

Dubos, R., Los sueños de la razón, trad. J. Almela, UNAM, México, 1996.

EISENHART, J., De usu principiorum moralis philosophiae in jure civili condendo et interpretando Commentarius, Helmstadt, 1726.

Etcheberry, J.B., «El ocaso del Positivismo Jurídico Incluyente», Persona y Derecho, vol. 67 (2012), pp. 411-447

Falk, R. A. y Schuman, S. I., «The Bellagio Conference on Legal Positivism», fournal of Legal Education, n. ${ }^{\circ} 14$ (1961), pp. 213-228

FreY, G., La matematización de nuestro universo, trad. J. Barrio, Gregorio del Toro, Madrid, 1972.

Gonseth, F., La géometrie et la problème de l'espace, Dunond Éditeur, Paris--Éditions du Griffon-Neuchâtel, 1955.

HäBERLE, P., La libertad fundamental en el Estado constitucional, trad. J. Seligman-C. Landa, Comares, Granada, 2003. 
Habermas, J La lógica de las ciencias sociales, trad. M. Jiménez Redondo, Tecnos, Madrid, 1988.

- Perfiles filosófico-políticos, trad. M. Jiménez Redondo, Taurus, Madrid, 1986.

Harrison, F., On Furisprudence and the Conflicts on Law, Oxford, 1910.

HaRT, H.L.A., El concepto del derecho, trad. Genaro. R. Carrió, Abeledo-Perrot, Buenos Aires, 1961.

Heck, P., Geblen, Bad Homburg vor der Höhe-Berlin-Zürich, 1968 (1912)

HegeL, G.W.F., Lecciones sobre la bistoria de la filosofía, trad. de W. Roces, FCE, México, 1985, vol. III.

Hegel, G.W.F., Principios de la Filosofía del derecho o derecho natural y ciencia política, trad. J.L. Vermal, Sudamericana, Buenos Aires, 1973, \$35, Zusatz.

HobBes, T., Elements of Philosophy, London, 1839.

JHERING, R., Die geschitlich-gesellschatliche Grundlagen der Ethik, «Jahrbuch für Gesetzgebung, Verwaltung und Volkswirtschaft» (Smoller's Jahrbücher) 6. Jahrgang, 1882, Erstes Heft.

Kant. I., Crítica de la razón pura, trad. P. Ribas, Alfaguara, Madrid, 1988, A43-A44.

Kelsen-Cossio, Problemas escogidos de la Teoría Pura del Derecho, Guillermo Kraft Limitada, trad. de C. Cossio, Buenos Aires, 1952.

Kelsen, H., Reine Rechtslebre, Frank Deuticke, Wien, 1960.

KIERKEgAaRD, S., La enfermedad mortal (o de la desesperación y el pecado), trad. D. G. Rivero, Guadarrama, Madrid, 1969.

KNAPP, L, System der Rechtsphilosophie, Erlangen, 1857.

Lightwood, J.M., The Nature of Positive Law, London, 1883.

LOCKE, J., «Essay of Human Understanding», en The Works of Fohn Locke, London, 1823 , vol. I.

LORIMER, J., The Institutes of Law, Edinburgh, $2^{\mathrm{a}}$ ed., 1880.

Luhmann, N., Complejidady Modernidad: de la unidad a la diferencia, trad. J. Beriain y J.M. García Blanco, Trotta, Madrid, 1998.

MacIntyre, A., Tras la virtud, trad. de Amelia Valcárcel, Crítica, Barcelona, 1987.

Major, J., De libertate christiana liber, Lovanii, 1540.

MASCOVIUS, G., sus Quaestiones selectae iuris naturae et gentium inter Grotium et Pufendorfium, Leipzig, 1768.

Massini CoRreas, C. I., Constructivismo ético y justicia procedimental en fohn Rawls, Unam, México, 2004.

- Los derechos humanos en el pensamiento actual, Abeledo-Perrot, Buenos Aires, 1994.

Molina, L., De justitia et jure opera omnia, Venetiis, 1614, Tract. II, disputatio. 23, col. 105.

NetTelbladt, D., Systema elementare universae jurisprudentiae naturalis in usum praelectionum academicarum adornatum, Halae Magdeburgicae, $3^{\text {a }}$ ed., 1767, $\$ 31$.

OскНАм, G., Magistri Guilhelmi de Ockham super potestate de summi pontificis octo quaestionum decisiones, Lyon, 1496, L. II, Dist. 28, q. Unica.

Ollero, A., Derechos humanos. Entre la moral y el derecho, UNAM, México DF, 2007.

Polaino-Lorente, A., Antropología e investigación en las ciencias humanas, Unión Editorial, Madrid, 2010. 
Pufendorf, S., De Iure naturae et gentium libri octo, Francofurti et Lipsiae, 1759.

Ramos Pascua, J.A., «Balance crítico de la filosofía jurídica de H. L. A. Hart», en Dikaiosyne (enero-junio 2009), pp. 131-144.

RAWLs, J., Liberalismo político, trad. S. R. Madero, FCE, México, 1996.

RIPERT, G., La regla moral en las obligaciones civiles, trad. Carlos Valencia Estrada, Ediciones Olejnik, Valparaíso / Grupo Editorial Ibáñez, Bogotá, 2017.

Rosmini-Serbati, A., Filosofia del diritto, Milano, 1841, vol. I.

Rössig, C., De cautione in tractando jure naturae nostra in primis aetate maxime necessaria, Lipsiae, 1758.

SAUMELls, R., La ciencia y el ideal metódico, Rialp, Madrid, 1958.

- La geometría euclídea como teoría del conocimiento, Rialp, Madrid, 1970, p. 79.

SAVIGNY, F. C. von, System der heutigen römischen Rechts, Berlin, 1840, Band I, $\$ 56$.

Schmaub, J.J., Neues Systema des Recht der Natur, Göttingen, 1754, Segunda Parte, Dubia juris naturae, pp. 404-405.

Scoto, J., Fohannis Duns Scoti Doctoris Subtilis Ordinis Minorum Summa Theologica. Ex universis operibus ejus concinnata, juxta ordinem et dispositionem S. Thomae Aquinatis per Fratrem Hieronymus de Montefortino, Romae, 1728, I-II, q. 90.

SERNA, P., Filosofía del derecho y paradigmas epistemológicos. De la crisis del positivismo a las teorías de la argumentación jurídica y sus problemas, Porrúa, México, 2006.

Spaemann, R., Lo natural y lo racional. Ensayos de antropología. trad. D. Innerarity y J. Olmo, Rialp, Madrid, 1989.

SuÁREZ, F., Tractatus de Legibus ac Deo legislatore, Conimbricae, 1612, L. II, cap. 17, \$ 6.

Vigo, R., El jusnaturalismo actual. De M. Villey a f. Finnis, Fontaneda, México, 2003.

Waluchow, W.J., Positivismo furídico Incluyente, trad. de M. S. Gil y R. Tesona, Marcial Pons, Madrid, 2007.

Whewell, W., The Philosophy of Inductive Sciences Founded upon Their History, London, 1847 (Reprint de Johnson, 1967). 